Article

\title{
Thermodynamic Performance of a Double-Effect Absorption Refrigeration Cycle Based on a Ternary Working Pair: Lithium Bromide + Ionic Liquids + Water
}

\author{
Yiqun $\mathrm{Li}^{1}$, $\mathrm{Na} \mathrm{Li}^{2}$, Chunhuan Luo ${ }^{1,3}$ and Qingquan $\mathrm{Su}^{1,3, *}$ \\ 1 School of Energy and Environmental Engineering, University of Science and Technology Beijing, \\ Beijing 100083, China; liyiqun1616@163.com (Y.L.); luochunhuan@ustb.edu.cn (C.L.) \\ 2 State Grid Energy Conservation Service CO., Ltd., Beijing 100052, China; nalixiaoxiao@163.com \\ 3 Beijing Engineering Research Center for Energy Saving and Environmental Protection, University of Science \\ and Technology Beijing, Beijing 100083, China \\ * Correspondence: suqingquan@ustb.edu.cn
}

Received: 30 September 2019; Accepted: 31 October 2019; Published: 4 November 2019

\begin{abstract}
For an absorption cycle, a ternary working pair $\mathrm{LiBr}-[\mathrm{BMIM}] \mathrm{Cl}(2.5: 1) / \mathrm{H}_{2} \mathrm{O}$ was proposed as a new working pair to replace $\mathrm{LiBr} / \mathrm{H}_{2} \mathrm{O}$. The thermodynamic properties including specific heat capacity, specific enthalpy, density, and viscosity were systematically measured and fitted by the least-squares method. The thermodynamic performance of a double-effect absorption refrigeration cycle based on $\mathrm{LiBr}-[\mathrm{BMIM}] \mathrm{Cl}(2.5: 1) / \mathrm{H}_{2} \mathrm{O}$ was investigated under different refrigeration temperatures from $5{ }^{\circ} \mathrm{C}$ to $12{ }^{\circ} \mathrm{C}$. Results showed that the ternary working pair $\mathrm{LiBr}-[\mathrm{BMIM}] \mathrm{Cl}(2.5: 1) / \mathrm{H}_{2} \mathrm{O}$ had advantages in the operating temperature range and corrosivity. Compared with $\mathrm{LiBr} / \mathrm{H}_{2} \mathrm{O}$, the operating temperature range was $20^{\circ} \mathrm{C}$ larger, and the corrosion rates of carbon steel and copper were reduced by more than $50 \%$ at $453.15 \mathrm{~K}$. However, the double-effect absorption refrigeration cycle with $\mathrm{LiBr}-[\mathrm{BMIM}] \mathrm{Cl}(2.5: 1) / \mathrm{H}_{2} \mathrm{O}$ achieved a coefficient of performance (COPc) from 1.09 to 1.46 and an exergetic coefficient of performance $(E C O P c)$ from 0.244 to 0.238 , which were smaller than those based on $\mathrm{LiBr} / \mathrm{H}_{2} \mathrm{O}$ due to the higher generation temperature and larger flow ratio.
\end{abstract}

Keywords: Double-effect absorption refrigeration; ionic liquids; working pair; thermodynamic properties; thermodynamic performance

\section{Introduction}

An absorption heat pump (AHP), which can be driven by renewable energy or industrial waste heat for cooling or heating, is proven to have a great energy-saving potential in buildings. From the utilization of a driving heat source, the AHP cycle is divided into single-effect, double-effect, and multiple-effect AHP. The double-effect AHP has two generators, where the temperature of the driven heat source for the first generator is obviously higher than single-effect, and the vapor which is generated from the first generator is also the heat source of the second generator. The number of generators for multiple-effect AHP is correspondingly larger, and the grade of the driven heat source is further improved. The coefficient of performance (COP) of double-effect or multi-effect AHP is higher than single-effect AHP because the system can generate more vapor refrigerant per unit heat supplied. However, the improvement of $C O P$ is weakened upon increasing the number of effects due to the $C O P$ of each effect for double-effect or multiple-effect systems being lower than that for a single-effect system. Moreover, the higher number of effects leads to more system complexity. Therefore, the double-effect AHP cycle is more available commercially [1].

In the past few decades, many researchers studied the performance of a double-effect absorption heat pump system based on energy and exergy methods [2-8]. The effects of operation conditional 
variables, such as the temperature in different working parts of the cycle, effectiveness of solution heat exchangers, circulation ratio, driving heat source, etc. on the thermodynamic performance were investigated. These studies had great significance in evaluating and optimizing the performance. However, among these systems, $\mathrm{LiBr} / \mathrm{H}_{2} \mathrm{O}$ was usually used as the working pair, which has risks of crystallization and corrosion at a high concentration and temperature. Thus, many researchers made continued efforts to resolve these issues using different methods such as corrosion inhibitors, anticorrosion materials, new working fluids, etc.

The addition of inhibitors is an economical way to reduce the corrosivity of $\mathrm{LiBr} / \mathrm{H}_{2} \mathrm{O} . \mathrm{OH}^{-}$, chromate, tungstate, molybdate, nitrate, tetraborate, or some other complexes are usually added to the $\mathrm{LiBr} / \mathrm{H}_{2} \mathrm{O}$ solution as the inhibitors in absorption system [9-12]. These inhibitors are helpful to reduce the corrosion of metallic materials by forming a passive film on the metal sample surface. Nonetheless, at a high-level temperature, especially above $165^{\circ} \mathrm{C}$, the corrosion rate is too high for practical application. The corrosivity of $\mathrm{LiBr} / \mathrm{H}_{2} \mathrm{O}$ to various corrosion-resistant metals, including austenitic stainless steel, $\mathrm{Cu}-\mathrm{Ni}$ alloys, and duplex stainless steel, was studied using the mass loss method and electrochemical method [13-17]. The corrosion rate decreases significantly when using high-nickel, high-molybdenum, and high-chromium alloys at a relatively low temperature and concentration; however, the metallic materials undergo pitting corrosion when the temperature and concentration are higher.

Some researchers worked on new working fluids instead of $\mathrm{LiBr} / \mathrm{H}_{2} \mathrm{O}$ which mainly included organic mixtures, salt solutions, and ionic liquids (ILs) [18]. However, among these working fluids, only a few were adopted in double-effect or multi-effect AHP systems. A quaternary working fluid $\mathrm{LiNO}_{3}-\mathrm{KNO}_{3}-\mathrm{NaNO}_{3} / \mathrm{H}_{2} \mathrm{O}$ was compatible with austenitic stainless-steel materials at high temperature up to approximately $260^{\circ} \mathrm{C}$, but the solubility of this working fluid was too low [19]. Organic fluid mixtures, such as trifluoroethanol (TFE)-tetraethylenglycol dimethylether (TEGDME), methanol-TEGDME, TFE- $N$-methy1-2-pyrrolidone (NMP), and TFE-2-pyrrolidone (PYR), were investigated as new working fluids by several researchers $[20,21]$. These organic working fluids with wide working temperature ranges are stable at a higher temperature and not very corrosive to general metals, whereas TFE and methanol are inflammable and toxic. As mentioned above, the issue for double-effect or multi-effect AHP systems is still not well settled.

Recently, $\mathrm{LiBr}-[\mathrm{BMIM}] \mathrm{Cl}(2.5: 1) / \mathrm{H}_{2} \mathrm{O}$ was proposed as a working pair in AHP [22]. The crystallization temperature, saturated vapor pressure, and corrosivity of this working pair were studied, and the results showed that its crystallization temperature and corrosivity were both lower than the common working pair $\mathrm{LiBr} / \mathrm{H}_{2} \mathrm{O}$. To further evaluate this alternative working pair, some other important thermodynamic properties including density, viscosity, specific heat capacity, and specific enthalpy were systematically measured, and the performance of a double-effect absorption refrigeration cycle based on $\mathrm{LiBr}-[\mathrm{BMIM}] \mathrm{Cl}(2.5: 1) / \mathrm{H}_{2} \mathrm{O}$ was investigated and compared with that using $\mathrm{LiBr} / \mathrm{H}_{2} \mathrm{O}$.

\section{Measuring Method and Thermodynamic Properties}

The concentration purities of the reagents used in this work are shown in Table 1. The reagents were used without further purification. 
Table 1. Provenance and mass fraction purity of the reagents.

\begin{tabular}{|c|c|c|}
\hline Reagent & Mass Fraction Purity & Provenance \\
\hline$[\mathrm{BMIM}] \mathrm{Cl}{ }^{\mathrm{a}}$ & $>0.99$ & Shanghai Chengjie Chemical \\
\hline $\mathrm{LiBr}$ & $>0.995$ & Tianjin Jinke Chemical \\
\hline $\mathrm{KCl}$ & $>0.99$ & Sinopharm Chemical Reagent Beijing \\
\hline $\mathrm{Li}_{2} \mathrm{CrO}_{4}$ & $>0.99$ & Tianjin Jinke Chemical \\
\hline $\mathrm{Na}_{2} \mathrm{SiO}_{3}$ & $>0.995$ & Tianjin Guangfu Chemical \\
\hline Polyaspartate & $>0.99$ & Xiya Chemical \\
\hline Pure water & & Home made \\
\hline
\end{tabular}

The crystallization temperature was measured by a dynamic method in a precision thermostat (HX-3010, Bilang, Shanghai, China). The prepared solution was put in the thermostat at a slightly higher initial temperature. Crystallization temperature was measured by reducing the temperature by $1{ }^{\circ} \mathrm{C}$ every $12 \mathrm{~h}$ until crystallization appeared in the solution.

The saturated vapor pressure was measured using a static method. The solution was poured into an autoclave and assembled with a precision digital absolute pressure gauge (AX-110, Aoxin, Xi'an, China) and a Pt-100 thermocouple. The assembly was then placed in a precision oil bath (DKU-30, Jinghong, Shanghai) after pumping into a vacuum. The data of the pressure gauge and thermocouple were collected after stabilization.

The density and viscosity were measured in a precision viscometer oil bath (SYP1003-H, Zhongxi, Beijing, China). Density measurement was carried out by a capillary pycnometer with a capillary diameter of approximately $1 \mathrm{~mm}$. Viscosity measurement was carried out using Ubbelohde capillary viscometers with different fine capillaries.

Both the specific heat capacity and dissolution enthalpy were measured using a micro reaction calorimeter ( $\mu R C$, THT Co., Milton Keynes, UK). The measurement of specific heat capacity was conducted by making a $1{ }^{\circ} \mathrm{C}$ "step-change" in the measurement temperature. The dissolution enthalpy was measured using an isothermal method with a solid addition accessory. The specific enthalpy was obtained using the measured specific heat capacity and dissolution enthalpy.

The corrosion rates of carbon steel and copper in the solution were measured using a weight loss method. The sample was soaked in the solution for at least $200 \mathrm{~h}$ in a vacuum environment, and the mass change of the sample was weighed to calculate the corrosion rate.

All the thermodynamic properties were measured three times, and the averages were adopted. The detailed experimental apparatus and procedures were given in References [23-25]. The detailed data of the density, viscosity, specific heat capacity, and specific enthalpy for $\mathrm{LiBr}-[\mathrm{BMIM}] \mathrm{Cl}(2.5: 1) / \mathrm{H}_{2} \mathrm{O}$ are listed in Appendix A.

\section{Thermodynamic Analysis of a Double-Effect Absorption Refrigeration Cycle}

\subsection{Thermodynamic Calculation}

The typical points of this serial double-effect absorption refrigeration cycle are marked in Figure 1. To analyze the performance of the cycle, some assumptions are given below.

- The cycle is under a steady state.

- The kinetic and potential energies are negligible.

- Enthalpy of the fluid does not change when flowing through the expansion valve.

- The refrigerant leaving the condenser is saturated liquid.

- The refrigerant leaving the evaporator is saturated vapor. 


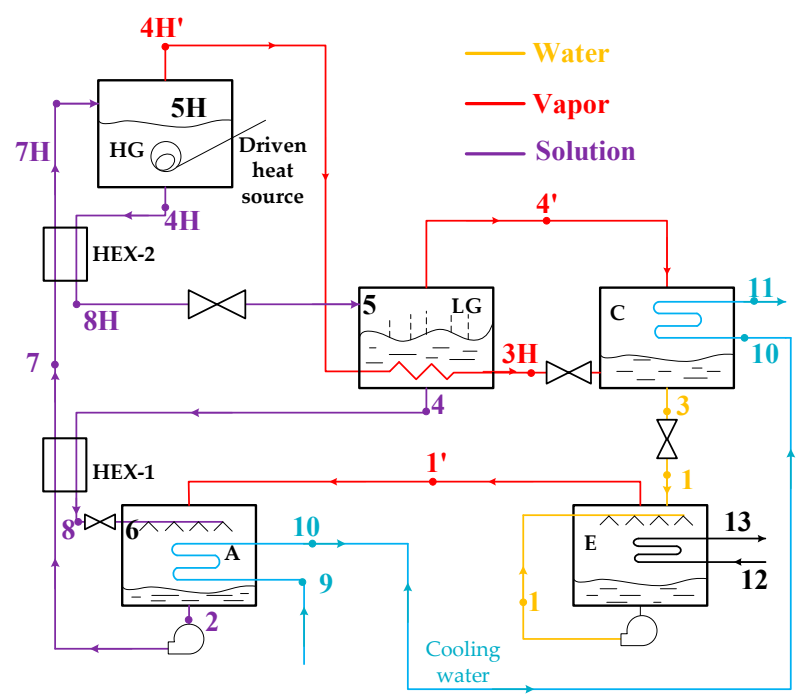

Figure 1. Schematic diagram of a double-effect absorption heat pump (AHP) cycle.

Based on energy, mass, and species conservations, the thermodynamic calculations of this cycle can be calculated using the following equations:

(1) High-pressure generator (HG)

$$
\begin{gathered}
m_{7 H}=m_{4 H}+m_{4 H^{\prime}}, \\
m_{7 H} w_{7 H}=m_{4 H} w_{4 H}, \\
q_{H G}=m_{4 H^{\prime}} h_{4 H^{\prime}}+m_{4 H} h_{4 H}-m_{7 H} h_{7 H} .
\end{gathered}
$$

(2) Low-pressure generator (LG)

$$
\begin{gathered}
m_{8 H}=m_{4^{\prime}}+m_{4}, \\
m_{8 H} w_{8 H}=m_{4} w_{4}, \\
q_{L G}=m_{4^{\prime}} h_{4^{\prime}}+m_{4} h_{4}-m_{8 H} h_{8 H} .
\end{gathered}
$$

As the calefaction heat in LG comes from the steam produced by the HG, the specific heat load $q_{\mathrm{LG}}$ can also be calculated using Equation (7).

$$
q_{L G}=m_{4 H^{\prime}}\left(h_{4 H^{\prime}}-h_{3 H}\right) .
$$

(3) Condenser

$$
\begin{gathered}
m_{3}=m_{4^{\prime}}+m_{3 H^{\prime}} \\
q_{C}=m_{4^{\prime}} h_{4^{\prime}}+m_{3 H} h_{3 H}-m_{3} h_{3} .
\end{gathered}
$$

(4) Evaporator

$$
\begin{gathered}
m_{1^{\prime}}=m_{3}, \\
q_{E}=m_{1^{\prime}} h_{1^{\prime}}-m_{3} h_{3} .
\end{gathered}
$$

(5) Absorber

$$
\begin{gathered}
m_{2}=m_{8}+m_{1^{\prime}}, \\
m_{2} w_{2}=m_{8} w_{8}, \\
q_{A}=m_{1^{\prime}} h_{1^{\prime}}+m_{8} h_{8}-m_{2} h_{2} .
\end{gathered}
$$


(6) Solution heat exchangers

$$
\begin{gathered}
q_{H E X-1}=m_{2}\left(h_{7}-h_{2}\right)=m_{8}\left(h_{4}-h_{8}\right), \\
q_{H E X-2}=m_{7 H}\left(h_{7 H}-h_{7}\right)=m_{4 H}\left(h_{4 H}-h_{8 H}\right), \\
\eta_{S H E-1}=\frac{t_{4}-t_{8}}{t_{4}-t_{2}} \\
\eta_{S H E-2}=\frac{t_{4 H}-t_{8 H}}{t_{4 H}-t_{7}} .
\end{gathered}
$$

(7) Solution pump

$$
\begin{aligned}
w_{s p} & =\frac{m_{7} \Delta p}{\rho_{7} \eta_{s p}}=\frac{a\left(m_{4 H^{\prime}}+m_{4^{\prime}}\right) \Delta p}{\rho_{7} \eta_{s p}}, \\
a & =\frac{m_{7}}{m_{4 H^{\prime}}+m_{4^{\prime}}}=\frac{w_{4}}{w_{4}-w_{7}},
\end{aligned}
$$

where $\Delta p(\mathrm{~Pa})$ is the sum of the total pressure drops and the difference in pressure between the high-pressure generator and the absorber. Frictional and minor pressure losses along the pipelines were calculated using Equations (21)-(24).

$$
\begin{gathered}
p_{f}=\lambda \frac{l}{d} \frac{\rho V^{2}}{2}, \\
p_{m}=\zeta \frac{\rho V^{2}}{2}, \\
\lambda=0.11\left(\frac{K}{d}+\frac{68}{\operatorname{Re}}\right)^{0.25}, \\
\operatorname{Re}=\frac{V d}{v} .
\end{gathered}
$$

(8) $C O P$ and $E C O P$

From the above equations, the coefficient of performance $(C O P)$ and exergetic coefficient of performance $(E C O P)$ of the double-effect absorption refrigeration cycle were calculated using Equations (25) and (26).

$$
\begin{gathered}
C O P=\frac{q_{E}}{q_{H G}+w_{s p}}, \\
E C O P=\frac{q_{E}\left(T_{0} / T_{E}-1\right)}{q_{H G}\left(1-T_{0} / T_{H G}\right)+w_{s p}} .
\end{gathered}
$$

\subsection{Thermodynamic Calculation Results}

In this work, the crystallization temperature and saturated vapor pressure of $\mathrm{LiBr}-[\mathrm{BMIM}] \mathrm{Cl}(2.5: 1) / \mathrm{H}_{2} \mathrm{O}$ were obtained from Reference [22] and the thermodynamic properties of $\mathrm{LiBr} / \mathrm{H}_{2} \mathrm{O}$ were obtained from References [25-29]. The properties of water and vapor were obtained from References [30-32]. Under the conditions in Table 2, the parameters of each point in Figure 1 could be obtained using the fitted equations of the properties and conservation equations with the Matlab program. Results for $\mathrm{LiBr}-[\mathrm{BMIM}] \mathrm{Cl}(2.5: 1) / \mathrm{H}_{2} \mathrm{O}$ and $\mathrm{LiBr} / \mathrm{H}_{2} \mathrm{O}$ are listed in Tables 3 and 4, respectively. The specific heat loads in different parts of the absorption refrigeration cycle are listed in Table 5. 
Table 2. Refrigeration conditions of the double-effect absorption cycle.

\begin{tabular}{|c|c|c|c|}
\hline \multicolumn{4}{|c|}{ Refrigeration Conditions } \\
\hline Cooling water temperature at inlet & $32{ }^{\circ} \mathrm{C}$ & Chilled water temperature at the inlet $\left(t_{12}\right)$ & $12^{\circ} \mathrm{C}$ \\
\hline Cooling water temperature at outlet & $42{ }^{\circ} \mathrm{C}$ & Chilled water temperature at the outlet $\left(t_{13}\right)$ & $7^{\circ} \mathrm{C}$ \\
\hline Temperature difference at the evaporator & $2{ }^{\circ} \mathrm{C}$ & Efficiency of the solution heat exchangers & 0.90 \\
\hline $\begin{array}{l}\text { Temperature difference at the absorber, } \\
\text { condenser, and generators }\end{array}$ & $3^{\circ} \mathrm{C}$ & $\begin{array}{l}\text { Difference of the mass concentration of the } \\
\text { both working pairs }\end{array}$ & $4 \%$ \\
\hline
\end{tabular}

Table 3. State parameters of streams in the cycle with $\mathrm{LiBr}-[\mathrm{BMIM}] \mathrm{Cl}(2.5: 1) / \mathrm{H}_{2} \mathrm{O}$.

\begin{tabular}{|c|c|c|c|c|c|c|c|}
\hline Points & Stream & Position & $w$ & $\begin{array}{c}t \\
\left({ }^{\circ} \mathrm{C}\right)\end{array}$ & $\begin{array}{c}p \\
(\mathbf{k P a})\end{array}$ & $\begin{array}{c}h \\
\left(\mathrm{~kJ} \cdot \mathrm{kg}^{-1}\right)\end{array}$ & $\begin{array}{c}m \\
\left(\mathrm{~kg} \cdot \mathrm{s}^{-1}\right)\end{array}$ \\
\hline $1^{\prime}$ & Vapor & Outlet of the evaporator & 0 & 5.0 & 0.872 & 2928.53 & 1.00 \\
\hline 1 & Water & Inlet of the evaporator & 0 & 5.0 & 0.872 & 439.63 & 1.00 \\
\hline 2 & $\begin{array}{l}\text { Weak } \\
\text { solution }\end{array}$ & Outlet of the absorber & 67.7 & 42.4 & 0.872 & 317.82 & 17.90 \\
\hline 3 & Water & Outlet of the condenser & 0 & 45.0 & 9.58 & 606.99 & 1.00 \\
\hline $3 \mathrm{H}$ & Water & $\begin{array}{l}\text { Outlet of the } \\
\text { low-pressure generator }\end{array}$ & 0 & 101.8 & 108.52 & 845.47 & 0.60 \\
\hline $4^{\prime}$ & Vapor & $\begin{array}{l}\text { Outlet of the } \\
\text { low-pressure generator }\end{array}$ & 0 & 98.8 & 9.58 & 3101.76 & 0.40 \\
\hline 4 & $\begin{array}{l}\text { Strong } \\
\text { solution }\end{array}$ & $\begin{array}{l}\text { Outlet of the } \\
\text { low-pressure generator }\end{array}$ & 71.7 & 98.8 & 9.58 & 463.13 & 16.90 \\
\hline $4 \mathrm{H}^{\prime}$ & Vapor & $\begin{array}{l}\text { Outlet of the } \\
\text { high-pressure generator }\end{array}$ & 0 & 164.9 & 108.52 & 3227.07 & 0.60 \\
\hline $4 \mathrm{H}$ & $\begin{array}{l}\text { Medium } \\
\text { solution }\end{array}$ & $\begin{array}{l}\text { Outlet of the } \\
\text { high-pressure generator }\end{array}$ & 70.0 & 164.9 & 108.52 & 582.94 & 17.30 \\
\hline 5 & $\begin{array}{l}\text { Medium } \\
\text { solution }\end{array}$ & Low-pressure generator & 70.0 & 95.2 & 9.58 & 437.43 & 17.30 \\
\hline 6 & $\begin{array}{l}\text { Strong } \\
\text { solution }\end{array}$ & Absorber & 71.7 & 48.0 & 0.872 & 363.76 & 16.90 \\
\hline 7 & $\begin{array}{l}\text { Weak } \\
\text { solution }\end{array}$ & $\begin{array}{l}\text { Outlet of the solution } \\
\text { heat exchanger }\end{array}$ & 67.7 & 87.4 & - & 411.65 & 17.90 \\
\hline $7 \mathrm{H}$ & $\begin{array}{l}\text { Weak } \\
\text { solution }\end{array}$ & $\begin{array}{l}\text { Outlet of the solution } \\
\text { heat exchanger }\end{array}$ & 67.7 & 154.3 & - & 552.29 & 17.90 \\
\hline 8 & $\begin{array}{l}\text { Strong } \\
\text { solution }\end{array}$ & $\begin{array}{l}\text { Outlet of the solution } \\
\text { heat exchanger }\end{array}$ & 71.7 & 48.0 & - & 363.76 & 16.90 \\
\hline $8 \mathrm{H}$ & $\begin{array}{l}\text { Medium } \\
\text { solution }\end{array}$ & $\begin{array}{l}\text { Outlet of the solution } \\
\text { heat exchanger }\end{array}$ & 70.0 & 95.2 & - & 437.43 & 17.30 \\
\hline 9 & $\begin{array}{l}\text { Cooling } \\
\text { water }\end{array}$ & Inlet of the absorber & 0 & 32.0 & - & - & - \\
\hline 10 & $\begin{array}{l}\text { Cooling } \\
\text { water }\end{array}$ & Outlet of the absorber & 0 & 39.4 & - & - & - \\
\hline 11 & $\begin{array}{l}\text { Cooling } \\
\text { water }\end{array}$ & Outlet of the condenser & 0 & 42.0 & - & - & - \\
\hline 12 & $\begin{array}{l}\text { Chilled } \\
\text { water }\end{array}$ & Inlet of the evaporator & 0 & 12.0 & - & - & - \\
\hline 13 & $\begin{array}{l}\text { Chilled } \\
\text { water }\end{array}$ & Outlet of the evaporator & 0 & 7.0 & - & - & - \\
\hline
\end{tabular}


Table 4. State parameters of streams in the cycle with $\mathrm{LiBr} / \mathrm{H}_{2} \mathrm{O}$.

\begin{tabular}{|c|c|c|c|c|c|c|c|}
\hline Points & Stream & Position & $w$ & $\begin{array}{c}t \\
\left({ }^{\circ} \mathrm{C}\right)\end{array}$ & $\begin{array}{c}p \\
(\mathbf{k P a})\end{array}$ & $\begin{array}{c}h \\
\left(\mathrm{~kJ} \cdot \mathrm{kg}^{-1}\right)\end{array}$ & $\begin{array}{c}m \\
\left(\mathrm{~kg} \cdot \mathrm{s}^{-1}\right)\end{array}$ \\
\hline $1^{\prime}$ & Vapor & Outlet of the evaporator & 0 & 5.0 & 0.872 & 2928.53 & 1.00 \\
\hline 1 & Water & Inlet of the evaporator & 0 & 5.0 & 0.872 & 439.63 & 1.00 \\
\hline 2 & $\begin{array}{l}\text { Weak } \\
\text { solution }\end{array}$ & Outlet of the absorber & 58.8 & 42.0 & 0.872 & 279.65 & 15.71 \\
\hline 3 & Water & Outlet of the condenser & 0 & 45.0 & 9.58 & 606.99 & 1.00 \\
\hline $3 \mathrm{H}$ & Water & $\begin{array}{l}\text { Outlet of the } \\
\text { low-pressure generator }\end{array}$ & 0 & 100.9 & 104.80 & 841.27 & 0.55 \\
\hline $4^{\prime}$ & Vapor & $\begin{array}{l}\text { Outlet of the } \\
\text { low-pressure generator }\end{array}$ & 0 & 97.9 & 9.58 & 3100.02 & 0.45 \\
\hline 4 & $\begin{array}{l}\text { Strong } \\
\text { solution }\end{array}$ & $\begin{array}{l}\text { Outlet of the } \\
\text { low-pressure generator }\end{array}$ & 62.8 & 97.9 & 9.58 & 384.89 & 14.71 \\
\hline $4 \mathrm{H}^{\prime}$ & Vapor & $\begin{array}{l}\text { Outlet of the } \\
\text { high-pressure generator }\end{array}$ & 0 & 158.8 & 104.80 & 3215.43 & 0.55 \\
\hline $4 \mathrm{H}$ & $\begin{array}{l}\text { Medium } \\
\text { solution }\end{array}$ & $\begin{array}{l}\text { Outlet of the } \\
\text { high-pressure generator }\end{array}$ & 60.9 & 158.8 & 104.80 & 500.33 & 15.16 \\
\hline 5 & $\begin{array}{l}\text { Medium } \\
\text { solution }\end{array}$ & Low-pressure generator & 60.9 & 93.1 & 9.58 & 375.97 & 15.16 \\
\hline 6 & $\begin{array}{l}\text { Strong } \\
\text { solution }\end{array}$ & Absorber & 62.8 & 47.6 & 0.872 & 293.15 & 14.71 \\
\hline 7 & $\begin{array}{l}\text { Weak } \\
\text { solution }\end{array}$ & $\begin{array}{l}\text { Outlet of the solution } \\
\text { heat exchanger }\end{array}$ & 58.8 & 85.8 & - & 365.55 & 15.71 \\
\hline $7 \mathrm{H}$ & $\begin{array}{l}\text { Weak } \\
\text { solution }\end{array}$ & $\begin{array}{l}\text { Outlet of the solution } \\
\text { heat exchanger }\end{array}$ & 58.8 & 148.3 & & 485.58 & 15.71 \\
\hline 8 & $\begin{array}{l}\text { Strong } \\
\text { solution }\end{array}$ & $\begin{array}{c}\text { Outlet of the solution } \\
\text { heat exchanger }\end{array}$ & 62.8 & 47.6 & - & 293.15 & 14.71 \\
\hline $8 \mathrm{H}$ & $\begin{array}{l}\text { Medium } \\
\text { solution }\end{array}$ & $\begin{array}{l}\text { Outlet of the solution } \\
\text { heat exchanger }\end{array}$ & 60.9 & 93.1 & - & 375.97 & 15.16 \\
\hline 9 & $\begin{array}{l}\text { Cooling } \\
\text { water }\end{array}$ & Inlet of the absorber & 0 & 32.0 & - & - & - \\
\hline 10 & $\begin{array}{l}\text { Cooling } \\
\text { water }\end{array}$ & Outlet of the absorber & 0 & 39.0 & - & - & - \\
\hline 11 & $\begin{array}{l}\text { Cooling } \\
\text { water }\end{array}$ & Outlet of the condenser & 0 & 42.0 & - & - & - \\
\hline 12 & $\begin{array}{l}\text { Chilled } \\
\text { water }\end{array}$ & Inlet of the evaporator & 0 & 12.0 & - & - & - \\
\hline 13 & $\begin{array}{l}\text { Chilled } \\
\text { water }\end{array}$ & Outlet of the evaporator & 0 & 7.0 & - & - & - \\
\hline
\end{tabular}

Table 5. The specific heat load at different parts of double-effect absorption heat pump (AHP). $\mathrm{COP}$ - coefficient of performance; ECOP—exergetic coefficient of performance.

\begin{tabular}{cccccccccc}
\hline Working Pairs & $\begin{array}{c}q_{H G} \\
(\mathbf{k W})\end{array}$ & $\begin{array}{c}q_{L G} \\
(\mathbf{k W})\end{array}$ & $\begin{array}{c}q_{C} \\
(\mathbf{k W})\end{array}$ & $\boldsymbol{q}_{E} \mathbf{( k W )}$ & $\begin{array}{c}\boldsymbol{q}_{A} \\
(\mathbf{k W})\end{array}$ & $\begin{array}{c}q_{S H E-1} \\
(\mathbf{k W})\end{array}$ & $\begin{array}{c}q_{S H E-2} \\
(\mathbf{k W})\end{array}$ & COPc & ECOPc \\
\hline $\mathrm{LiBr}-[\mathrm{BMIM}] \mathrm{Cl} / \mathrm{H}_{2} \mathrm{O}$ & 2134.14 & 1502.46 & 1142.50 & 2321.54 & 3388.27 & 1681.85 & 2520.97 & 1.09 & 0.244 \\
$\mathrm{LiBr} / \mathrm{H}_{2} \mathrm{O}$ & 1715.86 & 1366.15 & 1258.22 & 2321.54 & 2847.43 & 1349.08 & 1885.17 & 1.35 & 0.312 \\
\hline
\end{tabular}

From Tables 3 and 4, the calculation results show good mass and species conservation. The energy conservation can be further verified from Table 5 by Equation (27). The total heat input is defined as $q_{E}+q_{G}$, and the total heat output is defined as $q_{A}+q_{C}$. The total heat input and output for $\mathrm{LiBr}-[\mathrm{BMIM}] \mathrm{Cl} / \mathrm{H}_{2} \mathrm{O}$ were $4455.68 \mathrm{~kW}$ and $4530.77 \mathrm{~kW}$, respectively. The relative deviations between the total heat input and total heat output of the cycle were $1.68 \%$ for $\mathrm{LiBr}-[\mathrm{BMIM}] \mathrm{Cl} / \mathrm{H}_{2} \mathrm{O}$ and $1.69 \%$ for $\mathrm{LiBr} / \mathrm{H}_{2} \mathrm{O}$. The mass flow rate of the cooling water in the absorber was nearly identical to that in the condenser. Considering an acceptable relative deviation, the above mathematic equations and Matlab program in this work could be used to analyze the performance of a double-effect absorption 
refrigeration cycle. To further comprehensively compare it with $\mathrm{LiBr} / \mathrm{H}_{2} \mathrm{O}$, the thermodynamic performance of $\mathrm{LiBr}-[\mathrm{BMIM}] \mathrm{Cl} / \mathrm{H}_{2} \mathrm{O}$ was calculated under various evaporation temperature from $5{ }^{\circ} \mathrm{C}$ to $12{ }^{\circ} \mathrm{C}$. The chilled water temperatures $\left(t_{11}\right.$ and $\left.t_{12}\right)$ were changed with the evaporation temperature. The other operation conditions in Table 2 were kept invariant in the calculation.

$$
\left\{\begin{array}{l}
\left|\frac{\left(q_{E}+q_{H G}\right)-\left(q_{C}+q_{A}\right)}{\left(q_{E}+q_{H G}\right)}\right|<0.02 \\
D_{c 1}=\frac{q_{A} \times \rho_{A}}{4.186 \times\left(t_{10}-t_{9}\right)}=108 \mathrm{~kg} \cdot \mathrm{s}^{-1} \\
D_{c 2}=\frac{q_{C} \times \times_{c}}{4.186 \times\left(t_{11}-t_{10}\right)}=106 \mathrm{~kg} \cdot \mathrm{s}^{-1}
\end{array} .\right.
$$

\subsection{Thermodynamic Analysis and Discussion}

\subsubsection{Generation Temperature and Corrosion}

For a high-temperature absorption system, the generation temperature in the high-pressure generator has great influence on the required grade of the driving heat source and the corrosion to materials. As shown in Figure 2, as the evaporation temperature $t_{E}$ varied from $5{ }^{\circ} \mathrm{C}$ to $12{ }^{\circ} \mathrm{C}$, the generation temperature $t_{H G}$ in the HG decreased from $164.9^{\circ} \mathrm{C}$ to $140.4{ }^{\circ} \mathrm{C}$ and from $158.9^{\circ} \mathrm{C}$ to $137.3{ }^{\circ} \mathrm{C}$ for $\mathrm{LiBr}-[\mathrm{BMIM}] \mathrm{Cl} / \mathrm{H}_{2} \mathrm{O}$ and $\mathrm{LiBr} / \mathrm{H}_{2} \mathrm{O}$, respectively. The double-effect absorption refrigeration system based on $\mathrm{LiBr}-[\mathrm{BMIM}] \mathrm{Cl} / \mathrm{H}_{2} \mathrm{O}$ needs a higher generation temperature, leading to it requiring a higher grade of the driving heat source and facing a stronger corrosivity. The generation temperature $t_{L G}$ in the LG also decreased with the increasing $t_{E}$. The difference in $t_{L G}$ between $\mathrm{LiBr}-[\mathrm{BMIM}] \mathrm{Cl}(2.5: 1) / \mathrm{H}_{2} \mathrm{O}$ and $\mathrm{LiBr} / \mathrm{H}_{2} \mathrm{O}$ was slight.

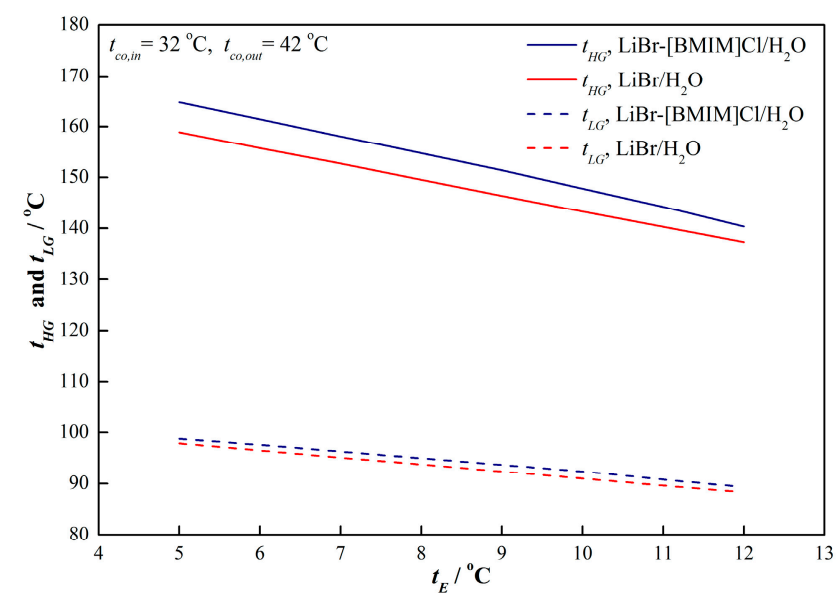

Figure 2. Variations of $t_{H G}$ and $t_{L g}$ with the evaporation temperature $t_{E}$.

The corrosion problem, which is generally faced in high-pressure generators, usually limits the applications of a high-temperature absorption system. To study the corrosivity of $\mathrm{LiBr}-[\mathrm{BMIM}] \mathrm{Cl}(2.5: 1) / \mathrm{H}_{2} \mathrm{O}$ and $\mathrm{LiBr} / \mathrm{H}_{2} \mathrm{O}$, the corrosion rates of carbon steel and copper in $70.0 \%$ $\mathrm{LiBr}-[\mathrm{BMIM}] \mathrm{Cl}(2.5: 1) / \mathrm{H}_{2} \mathrm{O}$ at $165^{\circ} \mathrm{C}$ and $60.9 \% \mathrm{LiBr} / \mathrm{H}_{2} \mathrm{O}$ at $159^{\circ} \mathrm{C}$, adding environmentally friendly complex inhibitors of $\mathrm{Na}_{2} \mathrm{SiO}_{3}$ at $w=0.004$ and polyaspartate (PASP) at $w=0.001$, were investigated using a weight loss method [33]. Figure 3 shows that the corrosion rates of carbon steel and copper in $\mathrm{LiBr}-[\mathrm{BMIM}] \mathrm{Cl}(2.5: 1) / \mathrm{H}_{2} \mathrm{O}$ were smaller than those in $\mathrm{LiBr} / \mathrm{H}_{2} \mathrm{O}$. Compared to carbon steel, copper exhibited much greater corrosion rates in both working pairs. 


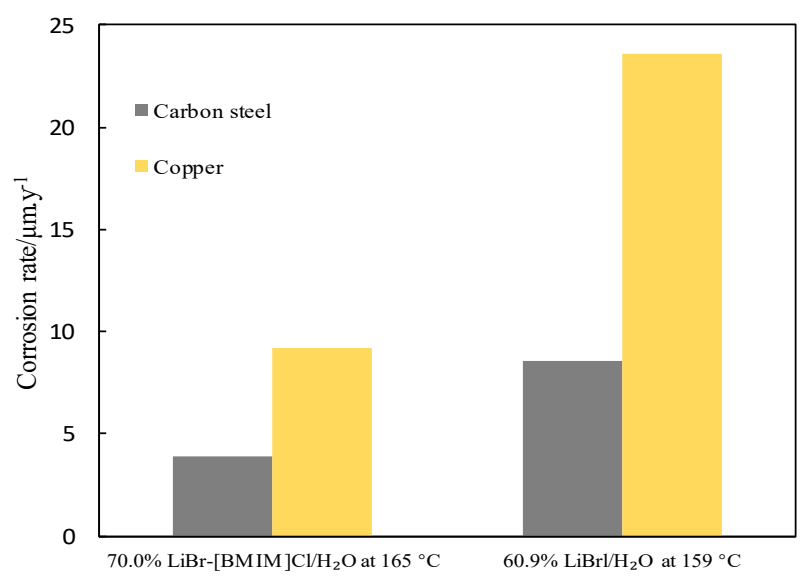

Figure 3. Corrosion rates of carbon steel and copper in $\mathrm{LiBr}-[\mathrm{BMIM}] \mathrm{Cl} / \mathrm{H}_{2} \mathrm{O}$ and $\mathrm{LiBr} / \mathrm{H}_{2} \mathrm{O}$.

In order to further analyze the corrosion phenomenon of copper, the surface morphologies of the metal samples soaked in the solutions of $\mathrm{LiBr}-[\mathrm{BMIM}] \mathrm{Cl}(2.5: 1) / \mathrm{H}_{2} \mathrm{O}$ and $\mathrm{LiBr} / \mathrm{H}_{2} \mathrm{O}$ were photographed using a scanning electron microscope (SEM), as shown in Figure 4. The copper surface for $\mathrm{LiBr}-[\mathrm{BMIM}] \mathrm{Cl}(2.5: 1) / \mathrm{H}_{2} \mathrm{O}$ was homogeneously covered with the solid corrosion products. In addition to the complex inhibitors, the organic cations in the imidazolium-based ionic liquids [BMIM]Cl would be adsorbed onto the metal surface to form an organic film, which would be helpful for inhibiting the ion transport and reducing the corrosion rate. In contrast, there was no protective layer overlaid on the copper surface for $\mathrm{LiBr} / \mathrm{H}_{2} \mathrm{O}$. Thus, the corrosivity of the ternary working pair was less than $\mathrm{LiBr} / \mathrm{H}_{2} \mathrm{O}$. Under the generation temperature around $160^{\circ} \mathrm{C}$ in the high-pressure generator, $\mathrm{LiBr}-[\mathrm{BMIM}] \mathrm{Cl} / \mathrm{H}_{2} \mathrm{O}$ had a strong anti-corrosion effect on the metal materials, which is beneficial for the lifetime of a high-temperature absorption system.
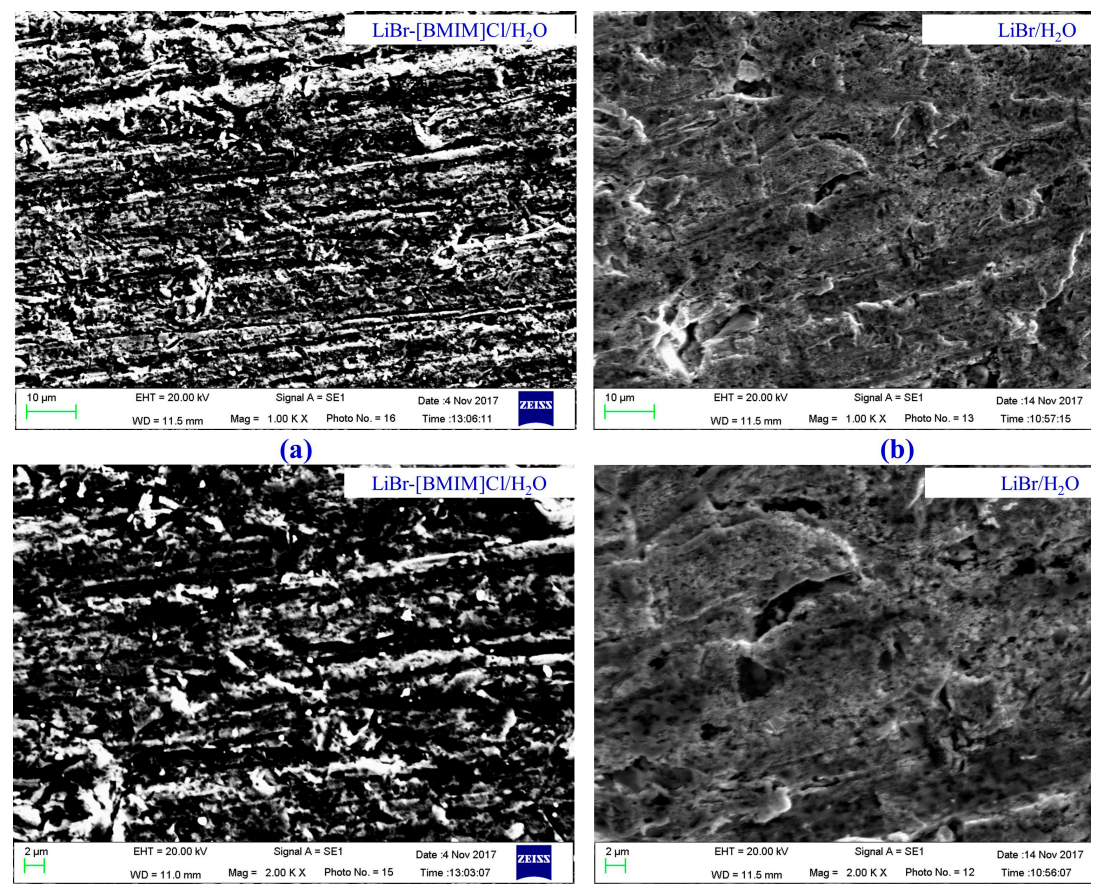

Figure 4. SEM micrograph of copper surface in the working pair with $w=0.004 \mathrm{Na}_{2} \mathrm{SiO}_{3}$ and $w=0.001$ polyaspartate: $(\mathbf{a}) \mathrm{LiBr}-[\mathrm{BMIM}] \mathrm{Cl} / \mathrm{H}_{2} \mathrm{O} ;(\mathbf{b}) \mathrm{LiBr} / \mathrm{H}_{2} \mathrm{O}$. 


\subsubsection{Crystallization Problem}

In addition to the corrosion issue, crystallization is another critical problem limiting the practical application of a high-temperature absorption refrigeration system. Crystallization risk generally occurs as the strong solutions flow through the solution heat exchangers (HEX), especially at the outlet of the HEX-1 (point 8). Thus, the operating temperature range, which is defined to be the difference between the $t_{8}$ and crystallization temperature $t_{c r}$, is not only closely related to the temperature $t_{8}$ but also depends on the concentration of the strong solution. Figure 5 shows the variation of the mass fractions of strong solution $w_{L G}$ with the evaporation $t_{E}$. $w_{L G}$ decreased from $w=0.717$ to $w=0.680$ and from $w=0.628$ to $w=0.586$ for $\mathrm{LiBr}-[\mathrm{BMIM}] \mathrm{Cl}(2.5: 1) / \mathrm{H}_{2} \mathrm{O}$ and $\mathrm{LiBr} / \mathrm{H}_{2} \mathrm{O}$, respectively, as $t_{E}$ increased from $5{ }^{\circ} \mathrm{C}$ to $12{ }^{\circ} \mathrm{C}$, whereby the former had a larger strong solution concentration. However, as shown in Figures 6 and 7, the operating temperature range of $\mathrm{LiBr}-[\mathrm{BMIM}] \mathrm{Cl}(2.5: 1) / \mathrm{H}_{2} \mathrm{O}$ was still larger than that of $\mathrm{LiBr} / \mathrm{H}_{2} \mathrm{O}$ because of its lower crystallization temperature. As $t_{E}$ increased from $5{ }^{\circ} \mathrm{C}$ to $12{ }^{\circ} \mathrm{C}$, the operating temperature range for $\mathrm{LiBr}-[\mathrm{BMIM}] \mathrm{Cl} / \mathrm{H}_{2} \mathrm{O}$ varied from $34.8^{\circ} \mathrm{C}$ to $56.9^{\circ} \mathrm{C}$, which was approximately $20^{\circ} \mathrm{C}$ larger than that for $\mathrm{LiBr} / \mathrm{H}_{2} \mathrm{O}$. In particular, at the lower refrigeration temperature, the operating temperature range for $\mathrm{LiBr} / \mathrm{H}_{2} \mathrm{O}$ was around $10^{\circ} \mathrm{C}$, and the crystallization risk could not be ignored due to the fluctuation of the concentration.

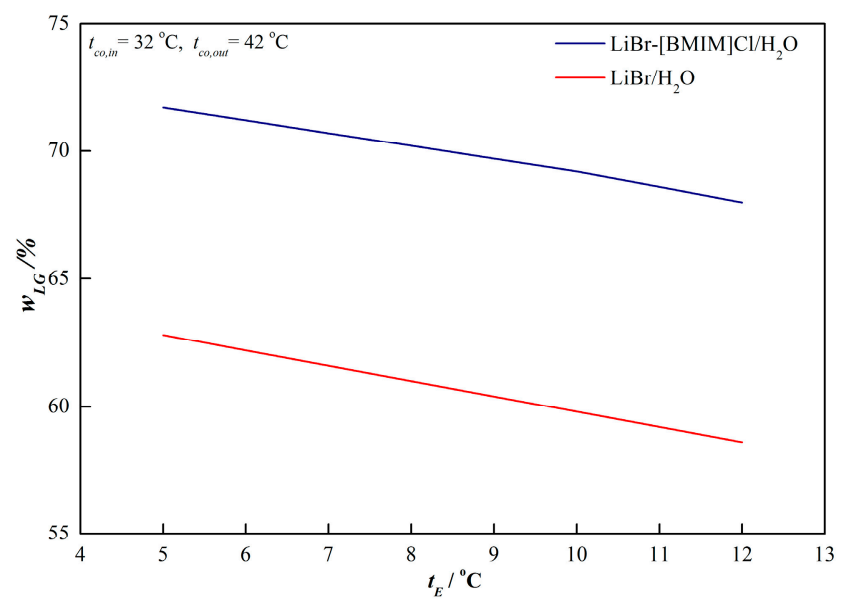

Figure 5. Variations of $w_{L G}$ with the evaporation temperature $t_{E}$.

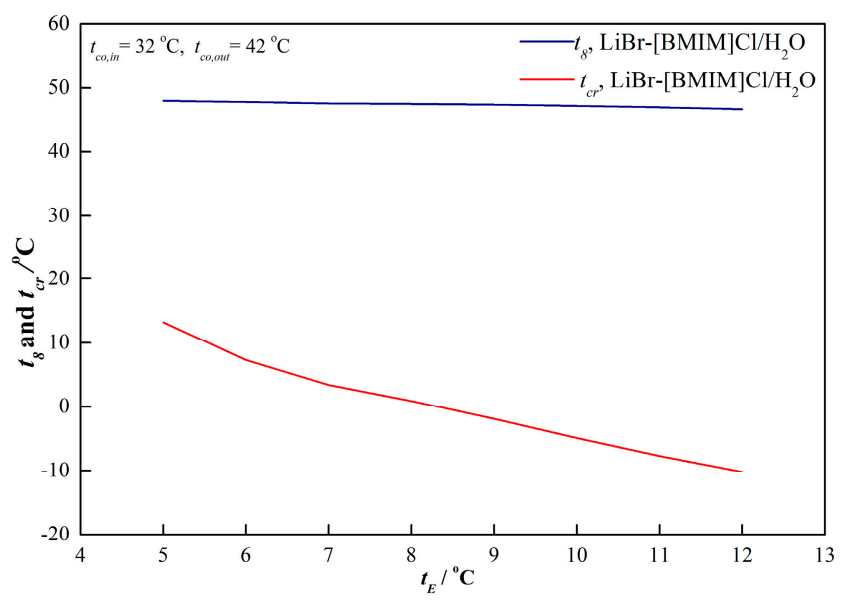

Figure 6. Variations of $t_{8}$ and $t_{\mathrm{cr}}$ for $\mathrm{LiBr}-[\mathrm{BMIM}] \mathrm{Cl} / \mathrm{H}_{2} \mathrm{O}$ with the evaporation temperature $t_{E}$. 


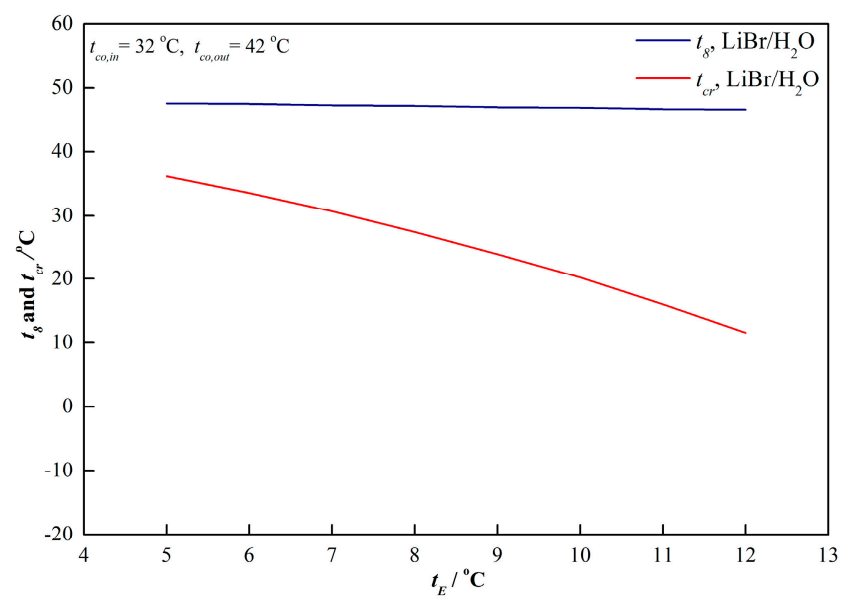

Figure 7. Variations of $t_{8}$ and $t_{\mathrm{cr}}$ for $\mathrm{LiBr} / \mathrm{H}_{2} \mathrm{O}$ with the evaporation temperature $t_{E}$.

\subsubsection{Solution Pump Power}

In most previous studies, the solution pump power was ignored because of its negligible value. In this work, the solution pump power was calculated based on the measured densities and viscosities. As exhibited in Figure 8, the solution pump power decreased with increasing $t_{E}$. According to Equation (19), the flow ratio $a$ had a great impact on the solution pump power. As shown in Figure 9, the flow ratio $a$ had a similar tendency with $w_{s p}$. Moreover, the double-effect absorption refrigeration cycle using $\mathrm{LiBr}-[\mathrm{BMIM}] \mathrm{Cl}(2.5: 1) / \mathrm{H}_{2} \mathrm{O}$ had a larger flow ratio because of a higher mass fraction of the strong solution, which led to a larger $w_{s p}$. Compared to the heat load in other parts in the absorption cycle, the solution pump power from $2 \mathrm{~kW}$ to $3.5 \mathrm{~kW}$ was really negligible, but the calculation was necessary for selecting the solution pump.

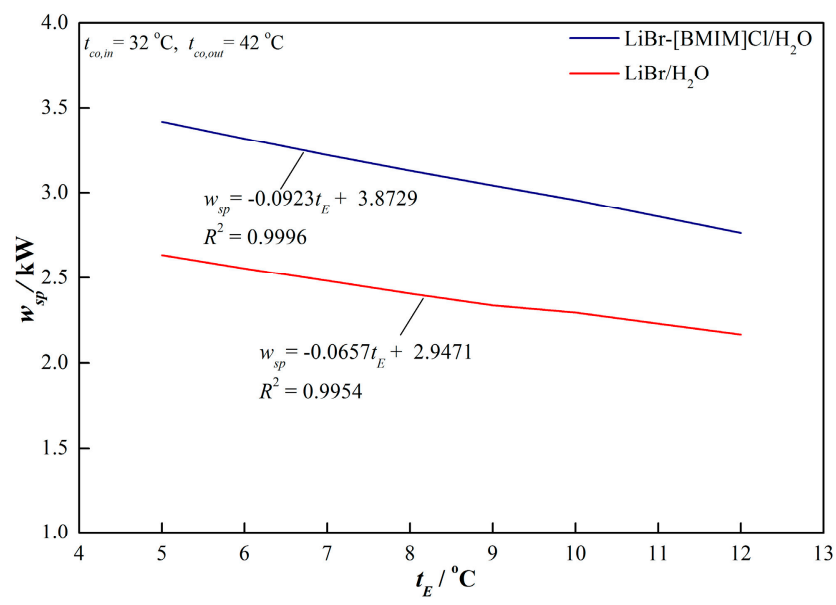

Figure 8. Variations of $w_{s p}$ with the evaporation temperature $t_{E}$. 


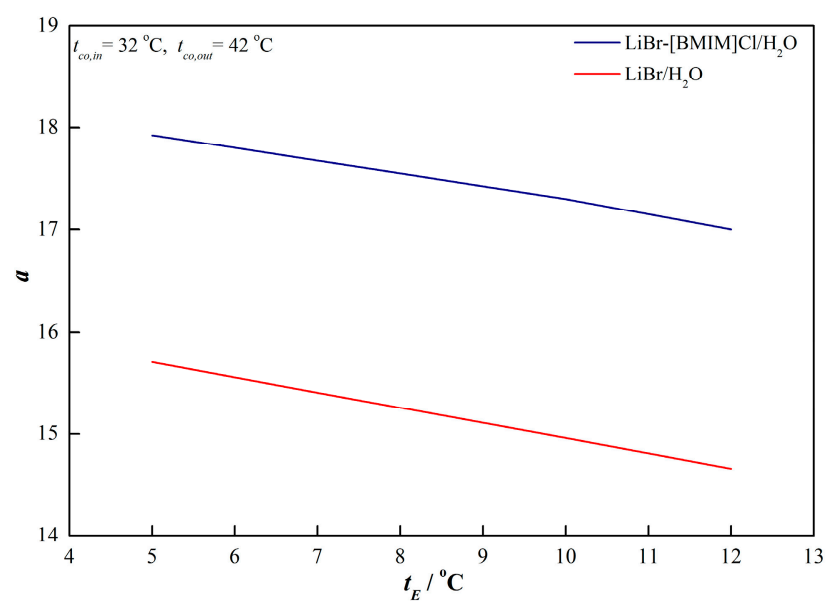

Figure 9. Variations of $a$ with the evaporation temperature $t_{E}$.

\subsection{4. $\mathrm{COP}_{\mathrm{c}}$}

$C O P_{c}$, the coefficient of performance for cooling, shows the energy utilization efficiency. The variation of $C O P_{\mathrm{c}}$ with $t_{E}$ is shown in Figure 10. As $t_{E}$ varied from $5{ }^{\circ} \mathrm{C}$ to $12{ }^{\circ} \mathrm{C}, C O P_{\mathrm{c}}$ increased from 1.09 to 1.46 and from 1.35 to 1.49 for $\mathrm{LiBr}-[\mathrm{BMIM}] \mathrm{Cl}(2.5: 1) / \mathrm{H}_{2} \mathrm{O}$ and $\mathrm{LiBr} / \mathrm{H}_{2} \mathrm{O}$, respectively. Obviously, the latter had a larger $C O P_{c}$. On the basis of Equation (25), $C O P_{c}$ can be further described by Equation (28).

$$
C O P=\frac{h_{1^{\prime}}-h_{3}}{a \times\left(\frac{w_{H G}-w_{A}}{w_{H G}} \times h_{4 h^{\prime}}+\frac{w_{A}}{w_{H G}} \times h_{4 h}-h_{7 h}\right)+w_{s p}} .
$$

Under a certain condensation temperature, $h_{3}$ is a constant. $h_{1^{\prime}}$ increases with increasing $t_{E}$. As shown in Figures 8 and 9 , both $w_{s p}$ and $a$ decreased with increasing $t_{E}$. The sum in the brackets was a positive value and also decreased with increasing $t_{E}$. Consequently, the $C O P_{c}$ showed a positive relationship with $t_{E}$. Because the double-effect absorption refrigeration cycle with $\mathrm{LiBr}-[\mathrm{BMIM}] \mathrm{Cl}(2.5: 1) / \mathrm{H}_{2} \mathrm{O}$ had a larger $a$ and $w_{s p}$, as well as a higher generation temperature corresponding to a higher $h_{4 h^{\prime}}$, it achieved a smaller $C O P_{c}$ compared to $\mathrm{LiBr} / \mathrm{H}_{2} \mathrm{O}$. However, the $C O P_{c}$ of $\mathrm{LiBr}-[\mathrm{BMIM}] \mathrm{Cl}(2.5: 1) / \mathrm{H}_{2} \mathrm{O}$ increased with a much larger slope and got close to that based on $\mathrm{LiBr} / \mathrm{H}_{2} \mathrm{O}$ at $t_{E}=12{ }^{\circ} \mathrm{C}$. This was mainly because the specific heat load in the high-pressure generator was reduced sharply due to the larger $a$. Additionally, the generation temperature and the corresponding $h_{4 h^{\prime}}$ were reduced more rapidly compared with that for $\mathrm{LiBr} / \mathrm{H}_{2} \mathrm{O}$.

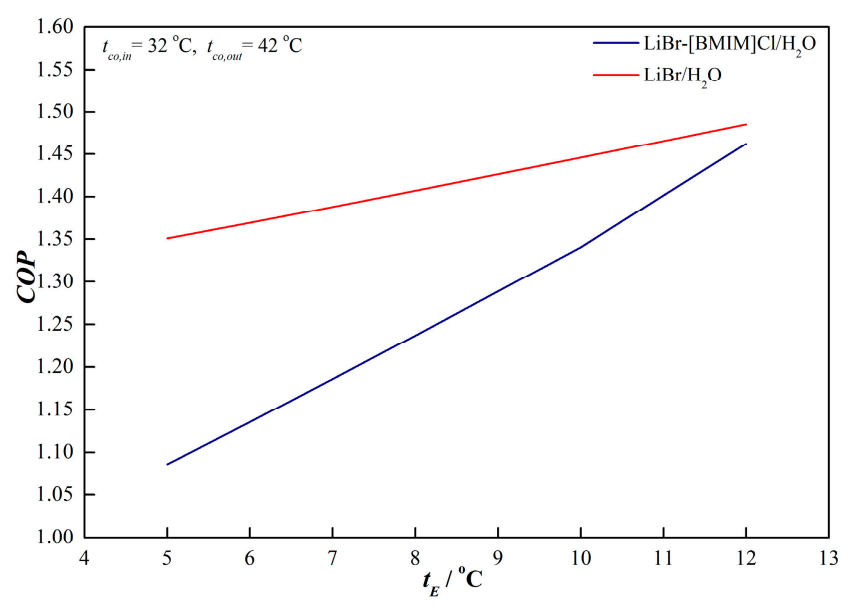

Figure 10. Variations of coefficient of performance $(C O P)$ with the evaporation temperature $t_{E}$. 


\subsection{5. $\mathrm{ECOP}_{\mathrm{c}}$}

$\mathrm{COP}_{c}$, which is based on the first law of thermodynamics, is important to analyze the thermal performance of an absorption system, $E C O P_{c}$ is usually used for further evaluating the performance of the absorption system based on the second law of thermodynamics. As we know, exergy is a measure of the usefulness and quality of energy, meaning the potential of the heat-to-work through a reversible thermodynamic process. Naturally, the analysis of $E C O P_{c}$ is significant for a double-effect absorption refrigeration cycle. As shown in Figure 11, ECOP $c$ varied from 0.244 to 0.238 and from 0.312 to 0.247 upon increasing $t_{E}$ from $5{ }^{\circ} \mathrm{C}$ to $12{ }^{\circ} \mathrm{C}$ for $\mathrm{LiBr}-[\mathrm{BMIM}] \mathrm{Cl}(2.5: 1) / \mathrm{H}_{2} \mathrm{O}$ and $\mathrm{LiBr} / \mathrm{H}_{2} \mathrm{O}$, respectively. Compared to $\mathrm{COP}_{c}, E C O P_{c}$ had a different variation tendency. $E C O P_{c}$ for $\mathrm{LiBr}-[\mathrm{BMIM}] \mathrm{Cl}(2.5: 1) / \mathrm{H}_{2} \mathrm{O}$ firstly increased slightly and then decreased with increasing $t_{E}$, and $E C O P_{c}$ for $\mathrm{LiBr} / \mathrm{H}_{2} \mathrm{O}$ also changed nonlinearly. This was mainly because $E C O P_{c}$ had a relationship with both the quantity and quality of energy. In Equation (26), the specific heat loads $q_{E}$ and $q_{H G}$ transformed from the driving heat source were the measures of quantity. $\left(T_{0} / T_{E}-1\right)$ and $\left(1-T_{0} / T_{H G}\right)$ were the efficiency of the heat-to-work by the Carnot engine operating between a constant temperature $T$ and ambient temperature $T_{0}$, i.e., the Carnot factor, showing the quality of the heat.

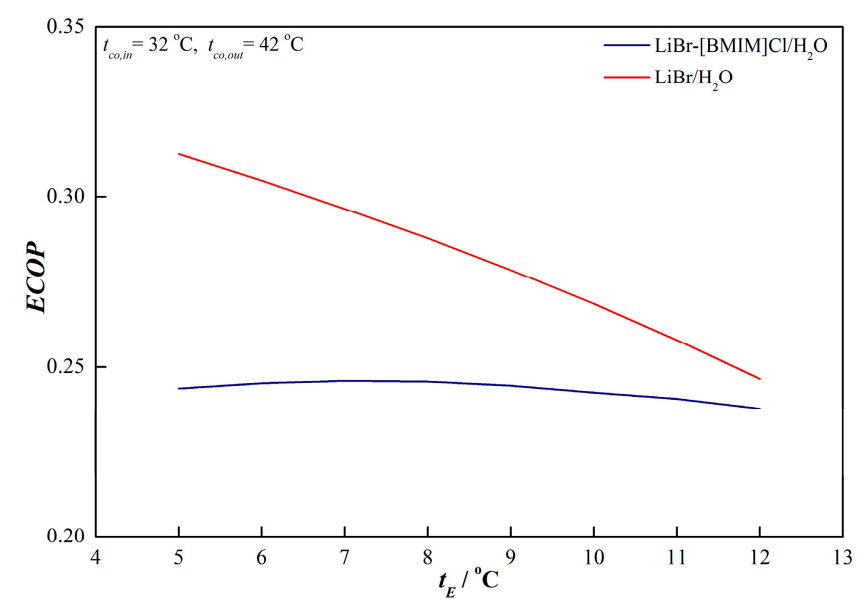

Figure 11. Variations of exergetic coefficient of performance (ECOP) with the evaporation temperature $t_{E}$.

To further investigate the effect of $t_{E}$ on $E C O P_{c}$, the variations of $q_{E}, q_{H G},\left(T_{0} / T_{E}-1\right)$, and (1 $\left.T_{0} / T_{H G}\right)$ are shown in Figure 12. $q_{H G},\left(T_{0} / T_{E}-1\right)$, and $\left(1-T_{0} / T_{H G}\right)$ decreased with increasing $t_{E}$ and $q_{E}$ increased with increasing $t_{E}$. The decreases in $q_{H G}$ and $\left(1-T_{0} / T_{H G}\right)$ were beneficial for improving $E C O P_{c}$. The increase in $q_{E}$ also had a positive contribution to $E C O P_{c}$, whereas the decrease in $\left(T_{0} / T_{E}\right.$ - 1) had negative contribution to $E C O P_{c}$. ECOP $P_{c}$ for $\mathrm{LiBr}-[\mathrm{BMIM}] \mathrm{Cl} / \mathrm{H}_{2} \mathrm{O}$ was somewhat less than that for $\mathrm{LiBr} / \mathrm{H}_{2} \mathrm{O}$ because of the larger $q_{H G}$ and $\left(1-\mathrm{T}_{0} / \mathrm{T}_{H G}\right) \cdot q_{H G}$ for $\mathrm{LiBr}-[\mathrm{BMIM}] \mathrm{Cl} / \mathrm{H}_{2} \mathrm{O}$ decreased much more rapidly as $t_{E}$ increased from $5{ }^{\circ} \mathrm{C}$ to $12{ }^{\circ} \mathrm{C}$, resulting in the reduction of the COOP $_{c}$ gap between both working pairs. $q_{E}, q_{H G},\left(T_{0} / T_{E}-1\right),\left(1-T_{0} / T_{H G}\right)$, and $w_{s p}$ almost changed linearly with the changing of $t_{E}$; thus, Equation (26) for $E C O P_{c}$ can be further described as follows:

$$
E C O P_{c}=\frac{f_{E}\left(t_{E}\right) \times \theta_{E}\left(t_{E}\right)}{f_{H G}\left(t_{E}\right) \times \theta_{H G}\left(t_{E}\right)+w_{s p}\left(t_{E}\right)} .
$$



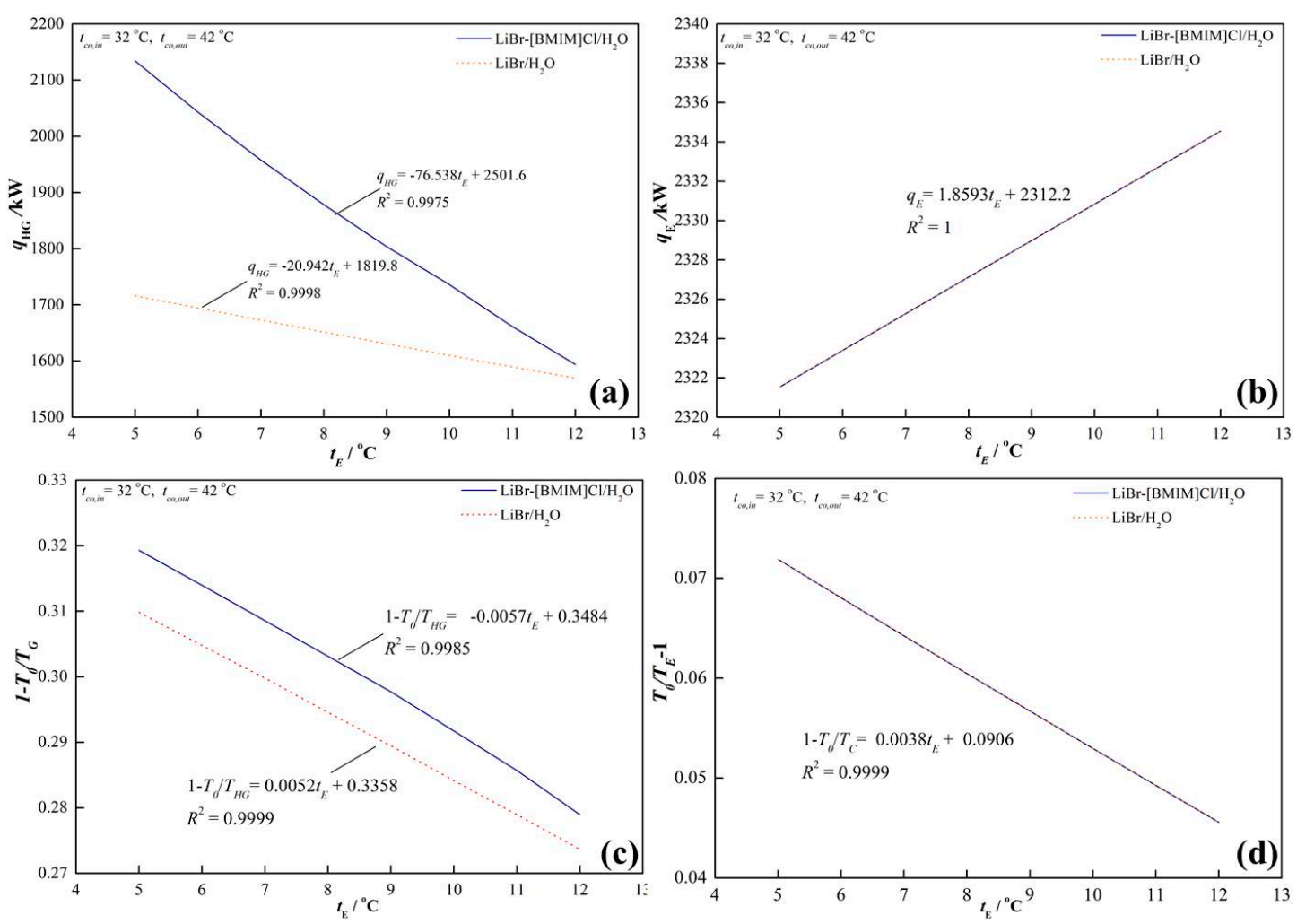

Figure 12. Variations of the specific heat loads and their quality with the evaporation temperature $t_{E}$. (a) $q_{E} ;(\mathbf{b}) q_{H G} ;(\mathbf{c})\left(1-T_{0} / T_{H G}\right) ;(\mathbf{d})\left(T_{0} / T_{E}-1\right)$.

Obviously, the $E C O P_{c}$ changed nonlinearly upon increasing the $t_{E}$. As the first-order derivative of the $E C O P_{c}$ is equal to zero, the theoretical maximum value of the $E C O P_{c}$ could be obtained, and the values were 0.246 (about $t_{E}=7{ }^{\circ} \mathrm{C}$ ) and 0.383 (about $t_{E}=-23^{\circ} \mathrm{C}$ ) for $\mathrm{LiBr}-[\mathrm{BMIM}] \mathrm{Cl} / \mathrm{H}_{2} \mathrm{O}$ and $\mathrm{LiBr} / \mathrm{H}_{2} \mathrm{O}$, respectively. As $t_{E}$ was below the transform temperature, the decreases in $q_{H G}$ and $\left(1-T_{0} / T_{H G}\right)$ had a dominant effect on the $E C O P_{c}$, resulting in an increase in $E C O P_{c}$. However, as the $t_{E}$ further increased, the decline in $\left(T_{0} / T_{E}-1\right)$ became the key factor leading to the reduction of the $E C O P_{c}$. Because $q_{H G}$ and $\left(1-T_{0} / T_{H G}\right)$ for $\mathrm{LiBr}-[\mathrm{BMIM}] \mathrm{Cl} / \mathrm{H}_{2} \mathrm{O}$ were larger than those for $\mathrm{LiBr} / \mathrm{H}_{2} \mathrm{O}$, the former had a larger transform temperature.

\subsubsection{Concentration Difference between Weak and Strong Solution}

The concentration difference between the weak solution and strong solution $(d c)$ also affects the performance of the absorption refrigeration cycle. To analyze the influence of $d c$, the thermodynamic performance of $\mathrm{LiBr}-[\mathrm{BMIM}] \mathrm{Cl} / \mathrm{H}_{2} \mathrm{O}$ and $\mathrm{LiBr} / \mathrm{H}_{2} \mathrm{O}$ was calculated under various $d c$ values from $3 \%$ to $7 \%$.

As shown in Figure 13, the high-pressure generator temperature $t_{H G}$ increased linearly with increasing $d c$ for both $\mathrm{LiBr}-[\mathrm{BMIM}] \mathrm{Cl} / \mathrm{H}_{2} \mathrm{O}$ and $\mathrm{LiBr} / \mathrm{H}_{2} \mathrm{O}$. At the same $t_{H G}$, the $d c$ of $\mathrm{LiBr} / \mathrm{H}_{2} \mathrm{O}$ was about $1.8 \%$ small than that of $\mathrm{LiBr}-[\mathrm{BMIM}] \mathrm{Cl} / \mathrm{H}_{2} \mathrm{O}$, which means $\mathrm{LiBr} / \mathrm{H}_{2} \mathrm{O}$ had a smaller circulation ratio, but higher crystallization temperature due to the high strong solution concentration. This was consistent with the previous analysis. The COP of the cycle for both working pairs also increased with increasing $d c$ in Figure 14. The difference in $t_{H G}$ or COP between $\mathrm{LiBr}-[\mathrm{BMIM}] \mathrm{Cl} / \mathrm{H}_{2} \mathrm{O}$ and $\mathrm{LiBr} / \mathrm{H}_{2} \mathrm{O}$ was tiny upon changing the $d c$. 


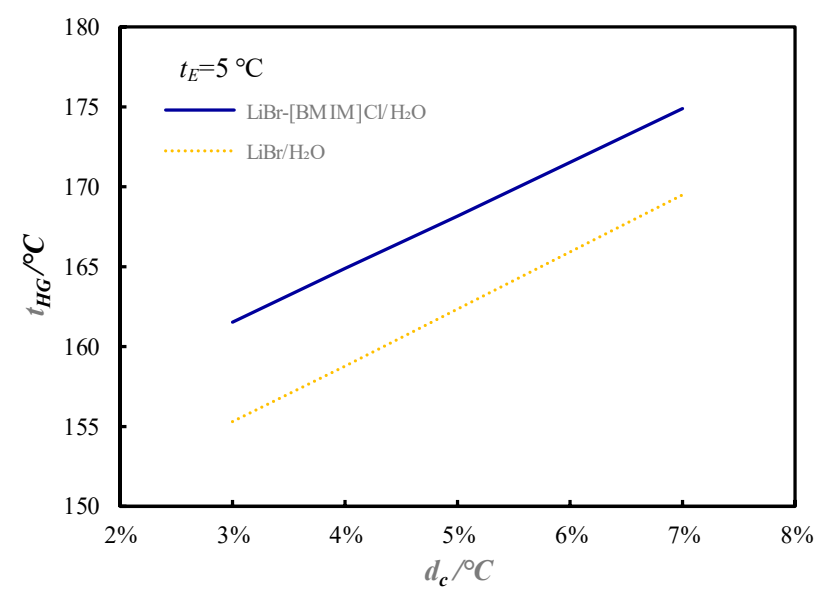

Figure 13. Variations of $t_{H G}$ with different $d_{c}$.

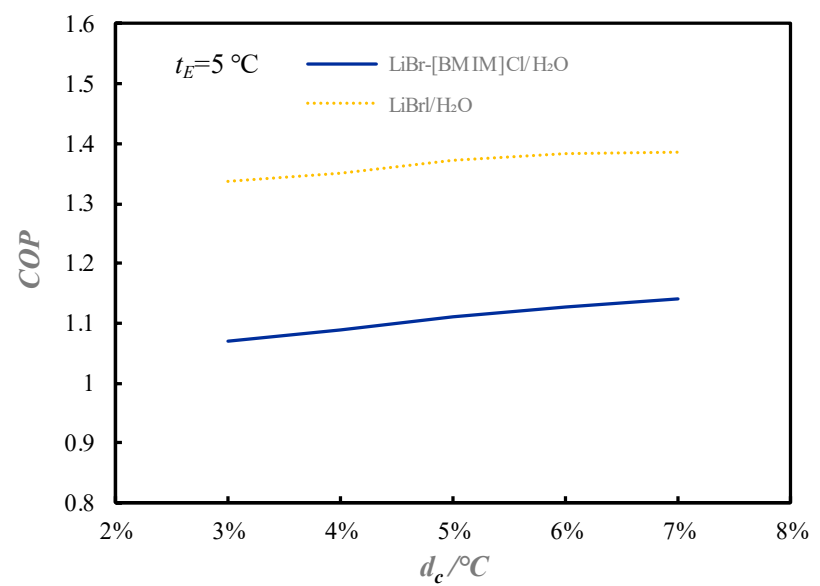

Figure 14. Variations of COP with different $d_{c}$.

\section{Conclusions}

Based on the properties of $\mathrm{LiBr}-[\mathrm{BMIM}] \mathrm{Cl}(2.5: 1) / \mathrm{H}_{2} \mathrm{O}$, the thermodynamic performance of a double-effect absorption refrigeration cycle with this working pair was analyzed and compared with $\mathrm{LiBr} / \mathrm{H}_{2} \mathrm{O}$ under different refrigeration temperatures from $5{ }^{\circ} \mathrm{C}$ to $12{ }^{\circ} \mathrm{C}$. Results showed that the operating temperature range for $\mathrm{LiBr}-[\mathrm{BMIM}] \mathrm{Cl}(2.5: 1) / \mathrm{H}_{2} \mathrm{O}$ was about $20{ }^{\circ} \mathrm{C}$ larger than that for $\mathrm{LiBr} / \mathrm{H}_{2} \mathrm{O}$. The solution pump power was negligible as it was much less than the specific heat loads of other parts of the absorption cycle. The double-effect absorption refrigeration cycle using $\mathrm{LiBr}-[\mathrm{BMIM}] \mathrm{Cl} / \mathrm{H}_{2} \mathrm{O}$ achieved $\mathrm{COP}_{c}$ from 1.09 to 1.46 , which was smaller than that using $\mathrm{LiBr} / \mathrm{H}_{2} \mathrm{O}$ due to the higher generation temperature and larger flow ratio. $E C O P_{c}$ for $\mathrm{LiBr}-[\mathrm{BMIM}] \mathrm{Cl} / \mathrm{H}_{2} \mathrm{O}$ varied from 0.244 to 0.238 , which was also smaller than that for $\mathrm{LiBr} / \mathrm{H}_{2} \mathrm{O}$. Although $\mathrm{LiBr}-[\mathrm{BMIM}] \mathrm{Cl} / \mathrm{H}_{2} \mathrm{O}$ had a higher generation temperature, it showed less corrosivity to carbon steel and copper compared to $\mathrm{LiBr} / \mathrm{H}_{2} \mathrm{O}$. Thus, as a potential working pair, $\mathrm{LiBr}-[\mathrm{BMIM}] \mathrm{Cl}(2.5: 1) / \mathrm{H}_{2} \mathrm{O}$ has some advantages for a double-effect absorption refrigeration cycle or other high-temperature AHP.

Author Contributions: Writing—original draft preparation, Y.L.; data curation, N.L.; methodology, C.L.; writing-review and editing, Q.S.

Funding: This work was supported by the National Key Research and Development Program of China (2016YFC0400408).

Conflicts of Interest: The authors declare no conflict of interest. 


\section{Nomenclature}

$\begin{array}{ll}{[\mathrm{BMIM}] \mathrm{Cl}} & \text { 1-butyl-3-methylimidazolium chloride } \\ a & \text { circulation ratio } \\ \mathrm{COP} P_{c} & \text { coefficient of performance } \\ C_{\mathrm{p}} & \text { specific heat capacity, } \mathrm{J}^{-1} \cdot \mathrm{K}^{-1} \\ E C O P_{c} & \text { exergy coefficient of performance } \\ h & \text { specific enthalpy, } \mathrm{kJ} \cdot \mathrm{kg}^{-1} \\ \mathrm{ILs} & \text { ionic liquids } \\ m & \text { mass flow rate of the solution, } \mathrm{kg} \cdot \mathrm{s}^{-1} \\ p & \text { vapor pressure, } \mathrm{kPa} \\ q & \text { specific heat load, } \mathrm{kJ} \cdot \mathrm{s}^{-1} \\ \mathrm{Re} & \text { Reynolds number } \\ T & \text { temperature, } \mathrm{K} \\ t & \text { temperature, }{ }^{\circ} \mathrm{C} \\ w & \text { mass fraction of absorbent } \\ \eta & \text { efficiency } \\ v & \text { viscosity, mm }{ }^{2} \cdot \mathrm{s}^{-1} \\ \rho & \text { density, g.cm } \\ \lambda & \text { frictional factor } \\ \zeta & \text { factor of local resistance } \\ \theta & \text { Carnot factor } \\ \mathrm{A} & \text { absorber } \\ \mathrm{C} & \text { condenser } \\ \mathrm{cr} & \text { crystallization } \\ \mathrm{E} & \text { evaporator } \\ \mathrm{HEX}-1, \mathrm{HEX}-2 & \text { solution heat exchanger } \\ \mathrm{HG} & \text { high-pressure generator } \\ \mathrm{LG} & \text { low-pressure generator } \\ \mathrm{sp} & \text { solution pump } \\ & \end{array}$

\section{Appendix A}

Table A1. Saturated vapor pressure at absorbent mass fraction $w$ of the system $\mathrm{LiBr}(1)+[\mathrm{BMIM}] \mathrm{Cl}$ (2) $+\mathrm{H}_{2} \mathrm{O}(3)$ at $p=0.1 \mathrm{MPa}$.

\begin{tabular}{|c|c|c|c|c|c|c|c|}
\hline$T(\mathrm{~K})$ & $p(\mathbf{k P a})$ & $T(\mathrm{~K})$ & $p(\mathbf{k P a})$ & $T(\mathrm{~K})$ & $p(\mathbf{k P a})$ & $T(\mathrm{~K})$ & $p(\mathbf{k P a})$ \\
\hline \multicolumn{2}{|c|}{$w_{1+2}=0.60$} & \multicolumn{2}{|c|}{$w_{1+2}=0.65$} & \multicolumn{2}{|c|}{$w_{1+2}=0.70$} & \multicolumn{2}{|c|}{$w_{1+2}=0.75$} \\
\hline 296.4 & 0.71 & 309.7 & 0.82 & 303.7 & 0.55 & 356.7 & 2.90 \\
\hline 316.4 & 2.06 & 323.3 & 1.70 & 313.4 & 0.96 & 367.5 & 4.89 \\
\hline 326.7 & 3.69 & 334.3 & 3.00 & 323.8 & 1.51 & 379.0 & 8.35 \\
\hline 336.5 & 5.98 & 345.9 & 5.57 & 332.4 & 2.91 & 389.5 & 12.77 \\
\hline 346.7 & 9.69 & 355.9 & 8.85 & 345.1 & 4.86 & 399.8 & 19.03 \\
\hline 357.8 & 15.28 & 365.3 & 13.34 & 355.3 & 7.80 & 410.4 & 27.76 \\
\hline 367.5 & 22.05 & 375.2 & 19.82 & 364.7 & 12.57 & 420.3 & 38.98 \\
\hline 377.8 & 32.60 & 384.5 & 28.22 & 375.1 & 18.59 & 429.9 & 56.05 \\
\hline 388.6 & 48.40 & 395.8 & 41.96 & 384.8 & 28.815 & 441.6 & 76.89 \\
\hline 400.2 & 71.00 & 405.7 & 59.23 & 396.5 & 40.84 & 449.6 & 98.50 \\
\hline \multirow[t]{2}{*}{408.7} & 92.65 & 415.4 & 79.80 & 405.6 & 58.25 & & \\
\hline & & 423.2 & 100.70 & 416.5 & 79.00 & & \\
\hline
\end{tabular}

The fitting equation was as follows:

$$
\lg p=\sum_{i=0}^{4}\left[A_{i}+B_{i} /\left(T-C_{i}\right)\right] w^{i}
$$


Table A2. Values of $A_{i}, B_{i}$, and $C_{i}$ for saturated vapor pressure.

\begin{tabular}{cccc}
\hline $\boldsymbol{i}$ & $\boldsymbol{A}_{\boldsymbol{i}}$ & $\boldsymbol{B}_{\boldsymbol{i}}$ & $\boldsymbol{C}_{\boldsymbol{i}}$ \\
\hline 0 & -1.0265478 & 39.616964 & 210.51137 \\
1 & 0.74875570 & -549.1808 & -302.38069 \\
2 & $-1.2196498 \times 10^{-2}$ & 18.494558 & -594.34163 \\
3 & $-1.2684596 \times 10^{-4}$ & $4.44125 \times 10^{-19}$ & -3.1545374 \\
4 & $1.5837523 \times 10^{-6}$ & $-6.24780 \times 10^{-4}$ & -306.48281 \\
\hline
\end{tabular}

Table A3. Density at absorbent mass fraction $w$ of the system $\mathrm{LiBr}(1)+[\mathrm{BMIM}] \mathrm{Cl}(2)+\mathrm{H}_{2} \mathrm{O}(3)$ at $p=0.1 \mathrm{MPa}^{a}$.

\begin{tabular}{|c|c|c|c|c|c|c|c|c|c|}
\hline$T(\mathrm{~K})$ & $\begin{array}{c}\rho \\
\left(\mathrm{g} \cdot \mathrm{cm}^{-3}\right)\end{array}$ & $T(\mathrm{~K})$ & $\begin{array}{c}\rho \\
\left(\mathrm{g} \cdot \mathrm{cm}^{-3}\right)\end{array}$ & $T(\mathrm{~K})$ & $\begin{array}{c}\rho \\
\left(\mathrm{g} \cdot \mathrm{cm}^{-3}\right)\end{array}$ & $T(\mathrm{~K})$ & $\begin{array}{c}\rho \\
\left(\mathrm{g} \cdot \mathrm{cm}^{-3}\right)\end{array}$ & $T(\mathrm{~K})$ & $\begin{array}{c}\rho \\
\left(\mathrm{g} \cdot \mathrm{cm}^{-3}\right)\end{array}$ \\
\hline \multicolumn{2}{|c|}{$w_{1+2}=0.55$} & \multicolumn{2}{|c|}{$w_{1+2}=0.60$} & \multicolumn{2}{|c|}{$w_{1+2}=0.65$} & \multicolumn{2}{|c|}{$w_{1+2}=0.70$} & \multicolumn{2}{|c|}{$w_{1+2}=0.75$} \\
\hline 303.15 & 1.384 & 303.15 & 1.434 & 303.15 & 1.49 & 303.15 & 1.549 & & \\
\hline 313.15 & 1.378 & 313.15 & 1.428 & 313.15 & 1.483 & 313.15 & 1.542 & & \\
\hline 323.15 & 1.372 & 323.15 & 1.422 & 323.15 & 1.477 & 323.15 & 1.535 & & \\
\hline 333.15 & 1.367 & 333.15 & 1.416 & 333.15 & 1.47 & 333.15 & 1.528 & 333.15 & 1.59 \\
\hline 343.15 & 1.361 & 343.15 & 1.411 & 343.15 & 1.464 & 343.15 & 1.521 & 343.15 & 1.582 \\
\hline 353.15 & 1.355 & 353.15 & 1.405 & 353.15 & 1.458 & 353.15 & 1.515 & 353.15 & 1.575 \\
\hline 363.15 & 1.349 & 363.15 & 1.399 & 363.15 & 1.452 & 363.15 & 1.508 & 363.15 & 1.568 \\
\hline 373.15 & 1.343 & 373.15 & 1.393 & 373.15 & 1.446 & 373.15 & 1.502 & 373.15 & 1.561 \\
\hline
\end{tabular}

${ }^{a}$ The mass ratio of $\mathrm{LiBr}$ to [BMIM]Cl was 2.5:1. Standard uncertainties $u$ were $u(T)= \pm 0.05 \mathrm{~K}, u\left(w_{1+2}\right)= \pm 0.2 \mathrm{wt} . \%$, and $u(p)= \pm 3.0 \mathrm{kPa}$, and the standard uncertainty $u$ was $u(\rho)= \pm 0.003 \mathrm{~g} \cdot \mathrm{cm}^{-3}$.

The fitting equation was as follows:

$$
\rho=\sum_{i=0}^{2}\left[\left(A_{i}+B_{i} T+C_{i} T^{2}\right) w^{i}\right] .
$$

Table A4. Values of $A_{i}, B_{i}$, and $C_{i}$ for density.

\begin{tabular}{cccc}
\hline $\boldsymbol{i}$ & $\boldsymbol{A}_{\boldsymbol{i}}$ & $\boldsymbol{B}_{\boldsymbol{i}}\left(\times \mathbf{1 0}^{-\mathbf{3}}\right)$ & $\boldsymbol{C}_{\boldsymbol{i}}\left(\times \mathbf{1 0}^{-5}\right)$ \\
\hline 0 & 0.384514 & 6.128884 & -1.221983 \\
1 & 2.024635 & -16.63302 & 3.272392 \\
2 & $8.490245 \times 10^{-2}$ & 8.778485 & -2.017801 \\
\hline
\end{tabular}

Table A5. Viscosity at absorbent mass fraction $w$ of the system $\mathrm{LiBr}(1)+[\mathrm{BMIM}] \mathrm{Cl}(2)+\mathrm{H}_{2} \mathrm{O}(3)$ at $p=0.1 \mathrm{MPa}^{a}$.

\begin{tabular}{|c|c|c|c|c|c|c|c|c|c|}
\hline$T(\mathrm{~K})$ & $\begin{array}{c}v \\
\left(\mathrm{~mm}^{2} \cdot \mathrm{s}^{-1}\right)\end{array}$ & $T(\mathrm{~K})$ & $\begin{array}{c}v \\
\left(\mathrm{~mm}^{2} \cdot \mathrm{s}^{-1}\right)\end{array}$ & $T(\mathrm{~K})$ & $\begin{array}{c}v \\
\left(\mathrm{~mm}^{2} \cdot \mathrm{s}^{-1}\right)\end{array}$ & $T(\mathrm{~K})$ & $\begin{array}{c}v \\
\left(\mathrm{~mm}^{2} \cdot \mathrm{s}^{-1}\right)\end{array}$ & $T(\mathrm{~K})$ & $\begin{array}{c}v \\
\left(\mathrm{~mm}^{2} \cdot \mathrm{s}^{-1}\right)\end{array}$ \\
\hline \multicolumn{2}{|c|}{$w_{1+2}=0.55$} & \multicolumn{2}{|c|}{$w_{1+2}=0.60$} & \multicolumn{2}{|c|}{$w_{1+2}=0.65$} & \multicolumn{2}{|c|}{$w_{1+2}=0.70$} & \multicolumn{2}{|c|}{$w_{1+2}=0.75$} \\
\hline 303.15 & 3.81 & 303.15 & 6.21 & 303.15 & 10.31 & 303.15 & 23.01 & & \\
\hline 313.15 & 3.01 & 313.15 & 4.88 & 313.15 & 7.82 & 313.15 & 16.13 & & \\
\hline 323.15 & 2.44 & 323.15 & 3.87 & 323.15 & 6.02 & 323.15 & 11.61 & & \\
\hline 333.15 & 1.99 & 333.15 & 3.06 & 333.15 & 4.66 & 333.15 & 8.39 & 333.15 & 21.29 \\
\hline 343.15 & 1.68 & 343.15 & 2.49 & 343.15 & 3.71 & 343.15 & 6.35 & 343.15 & 14.14 \\
\hline 353.15 & 1.46 & 353.15 & 2.11 & 353.15 & 3.05 & 353.15 & 4.94 & 353.15 & 10.00 \\
\hline 363.15 & 1.30 & 363.15 & 1.83 & 363.15 & 2.60 & 363.15 & 4.03 & 363.15 & 7.46 \\
\hline 373.15 & 1.18 & 373.15 & 1.63 & 373.15 & 2.22 & 373.15 & 3.34 & 373.15 & 5.81 \\
\hline
\end{tabular}

${ }^{a}$ The mass ratio of $\mathrm{LiBr}$ to [BMIM]Cl was 2.5:1. Standard uncertainties $u$ were $u(T)= \pm 0.05 \mathrm{~K}, u\left(w_{1+2}\right)= \pm 0.2 \mathrm{wt} . \%$, and $u(p)= \pm 3.0 \mathrm{kPa}$, and the relative standard uncertainty $u_{r}$ was $u_{r}(v)= \pm 0.03 v$. 
The fitting equation was as follows:

$$
\lg v=\sum_{i=0}^{3}\left[\left(A_{i}+B_{i} / T+C_{i} / T^{2}\right) w^{i}\right]
$$

Table A6. Values of $A_{i}, B_{i}$, and $C_{i}$ for viscosity.

\begin{tabular}{cccc}
\hline $\boldsymbol{i}$ & $\boldsymbol{A}_{\boldsymbol{i}}\left(\times \mathbf{1 0}^{\mathbf{2}}\right)$ & $\boldsymbol{B}_{\boldsymbol{i}}\left(\times \mathbf{1 0}^{\mathbf{4}}\right)$ & $\boldsymbol{C}_{\boldsymbol{i}}\left(\times \mathbf{1 0}^{\mathbf{6}}\right)$ \\
\hline 0 & 1.217521 & -5.828088 & 3.460217 \\
1 & -3.896274 & 13.818580 & 8.897532 \\
2 & 3.291964 & -1.092322 & -51.704210 \\
3 & -0.295650 & -9.908650 & 46.722780 \\
\hline
\end{tabular}

Table A7. Specific heat capacities at absorbent mass fraction $w$ of the system $\mathrm{LiBr}(1)+[\mathrm{BMIM}] \mathrm{Cl}(2)+$ $\mathrm{H}_{2} \mathrm{O}(3)$ at $p=0.1 \mathrm{MPa}^{a}$.

\begin{tabular}{|c|c|c|c|c|c|c|c|c|c|}
\hline$T(\mathrm{~K})$ & $\begin{array}{c}C_{p} \\
\left(\mathrm{~J} \cdot \mathrm{g}^{-1} \cdot \mathrm{K}^{-1}\right)\end{array}$ & $T(\mathrm{~K})$ & $\begin{array}{c}C_{p} \\
\left(\mathrm{~J} \cdot \mathrm{g}^{-1} \cdot \mathrm{K}^{-1}\right)\end{array}$ & $T(\mathrm{~K})$ & $\begin{array}{c}C_{p} \\
\left(\mathrm{~J} \cdot \mathrm{g}^{-1} \cdot \mathrm{K}^{-1}\right)\end{array}$ & $T(\mathrm{~K})$ & $\begin{array}{c}C_{p} \\
\left(\mathrm{~J} \cdot \mathrm{g}^{-1} \cdot \mathrm{K}^{-1}\right)\end{array}$ & $T(\mathrm{~K})$ & $\begin{array}{c}C_{p} \\
\left(\mathrm{~J} \cdot \mathrm{g}^{-1} \cdot \mathrm{K}^{-1}\right)\end{array}$ \\
\hline \multicolumn{2}{|c|}{$w_{1+2}=0.55$} & \multicolumn{2}{|c|}{$w_{1+2}=0.60$} & \multicolumn{2}{|c|}{$w_{1+2}=0.65$} & \multicolumn{2}{|c|}{$w_{1+2}=0.70$} & \multicolumn{2}{|c|}{$w_{1+2}=0.75$} \\
\hline 303.15 & 2.30 & 303.15 & 2.20 & 303.15 & 2.05 & 303.15 & 1.94 & & \\
\hline 313.15 & 2.32 & 313.15 & 2.21 & 313.15 & 2.07 & 313.15 & 1.96 & & \\
\hline 323.15 & 2.33 & 323.15 & 2.22 & 323.15 & 2.08 & 323.15 & 1.96 & & \\
\hline 333.15 & 2.34 & 333.15 & 2.22 & 333.15 & 2.10 & 333.15 & 1.97 & 333.15 & 1.85 \\
\hline 343.15 & 2.35 & 343.15 & 2.23 & 343.15 & 2.11 & 343.15 & 1.98 & 343.15 & 1.86 \\
\hline 353.15 & 2.38 & 353.15 & 2.24 & 353.15 & 2.12 & 353.15 & 2.01 & 353.15 & 1.88 \\
\hline 363.15 & 2.40 & 363.15 & 2.27 & 363.15 & 2.16 & 363.15 & 2.03 & 363.15 & 1.91 \\
\hline 373.15 & 2.45 & 373.15 & 2.30 & 373.15 & 2.19 & 373.15 & 2.07 & 373.15 & 1.93 \\
\hline
\end{tabular}

${ }^{a}$ The mass ratio of $\mathrm{LiBr}$ to [BMIM]Cl was 2.5:1. Standard uncertainties $u$ were $u(T)= \pm 0.01 \mathrm{~K}, u\left(w_{1+2}\right)= \pm 0.2 \mathrm{wt} . \%$, and $u(p)= \pm 3.0 \mathrm{kPa}$, and the standard uncertainty $u$ was $u\left(C_{p}\right)= \pm 0.05 \mathrm{~J} \cdot \mathrm{g}^{-1} \cdot \mathrm{K}^{-1}$.

The fitting equation was as follows:

$$
C_{p}=\sum_{i=0}^{2}\left[\left(A_{i}+B_{i} T+C_{i} T^{2}\right) w^{i}\right]
$$

Table A8. Values of $A_{i}, B_{i}$, and $C_{i}$ for specific heat capacity.

\begin{tabular}{cccc}
\hline $\boldsymbol{i}$ & $\boldsymbol{A}_{\boldsymbol{i}}$ & $\boldsymbol{B}_{\boldsymbol{i}}\left(\times \mathbf{1 0}^{-\mathbf{2}}\right)$ & $\boldsymbol{C}_{\boldsymbol{i}}\left(\times \mathbf{1 0}^{-\mathbf{5}}\right)$ \\
\hline 0 & 4.656718 & -1.447759 & 3.392384 \\
1 & 3.182206 & -1.114172 & -1.471251 \\
2 & -6.925005 & 2.383878 & -1.126738 \\
\hline
\end{tabular}

Table A9. Specific heat capacities $\left(\mathrm{J} \cdot \mathrm{g}^{-1} \cdot \mathrm{K}^{-1}\right)$ of ionic liquid $[\mathrm{BMIM}] \mathrm{Cl}$ at $p=0.1 \mathrm{MPa}$ and different temperatures.

\begin{tabular}{cccccccccc}
\hline $\mathbf{2 8 3 . 1 5 K}$ & $\mathbf{2 9 3 . 1 5 K}$ & $\mathbf{3 0 3 . 1 5 K}$ & $\mathbf{3 1 3 . 1 5 K}$ & $\mathbf{3 2 3 . 1 5 K}$ & $\mathbf{3 3 3 . 1 5 K}$ & $\mathbf{3 4 3 . 1 5 K}$ & $\mathbf{3 5 3 . 1 5 K}$ & $\mathbf{3 6 3 . 1 5 K}$ & $\mathbf{3 7 3 . 1 5 K}$ \\
\hline 1.55 & 1.62 & 1.73 & 1.94 & 2.55 & 6.31 & 1.98 & 1.98 & 2.025 & 2.05 \\
\hline
\end{tabular}

Table A10. Dissolution enthalpies $\left(\mathrm{kJ} \cdot \mathrm{kg}^{-1}\right)$ at various mass fractions $w$ for $\mathrm{LiBr}-[\mathrm{BMIM}] \mathrm{Cl} / \mathrm{H}_{2} \mathrm{O}$ at $313.15 \mathrm{~K}$ and $p=0.1 \mathrm{MPa}$.

\begin{tabular}{ccccc}
\hline Mass fraction & $\mathbf{0 . 5 5}$ & $\mathbf{0 . 6 0}$ & $\mathbf{0 . 6 5}$ & $\mathbf{0 . 7 0}$ \\
\hline Dissolution enthalpy $/ \mathrm{kJ} \cdot \mathrm{kg}^{-1}$ & -160.66 & -173.93 & -189.89 & -168.04 \\
\hline
\end{tabular}


Equations for calculating specific enthalpy were as follows:

$$
\left\{\begin{array}{l}
h(T, w)=\int_{T_{0}}^{T} C_{p} d T+h\left(T_{0}, w\right) \\
h\left(T_{0}, w\right)=\sum_{i=1}^{i=3} w_{i} h_{i}+h^{E}\left(T_{0}, w\right) \\
h_{i}=\int_{T_{0}}^{T} C_{p, i} d T+418.60
\end{array}\right.
$$

where $h(T, w)(\mathrm{kJ} / \mathrm{kg})$ is the specific enthalpy of $\mathrm{LiBr}-[\mathrm{BMIM}] \mathrm{Cl} / \mathrm{H}_{2} \mathrm{O}$ at temperature $T(\mathrm{~K})$, mass fraction $w, h\left(T_{0}, w\right)$ $(\mathrm{kJ} / \mathrm{kg})$ is the specific enthalpy of $\mathrm{LiBr}-[\mathrm{BMIM}] \mathrm{Cl} / \mathrm{H}_{2} \mathrm{O}$ at temperature $T_{0}(\mathrm{~K})$, and mass fractions $w, w_{i}$, and $h_{i}$ are the mass fractions and specific enthalpies of the pure components in the ternary system; $h^{\mathrm{E}}\left(T_{0}, w\right)$ is the dissolution enthalpy of $\mathrm{LiBr}-[\mathrm{BMIM}] \mathrm{Cl} / \mathrm{H}_{2} \mathrm{O}$ at temperature $T_{0}(\mathrm{~K})$, and mass fraction $w, C_{p, i}\left(\mathrm{~kJ} \cdot \mathrm{kg}^{-1} \cdot \mathrm{K}^{-1}\right)$ is the specific heat capacity of the pure components. The reference data of the specific enthalpies of pure water and pure absorbents were specified to be $418.60 \mathrm{~kJ} \cdot \mathrm{kg}^{-1}\left(100 \mathrm{kcal} \cdot \mathrm{kg}^{-1}\right)$.

Table A11. Specific enthalpy $h$ at absorbent mass fraction $w$ of the system $\operatorname{LiBr}(1)+[\mathrm{BMIM}] \mathrm{Cl}(2)+$ $\mathrm{H}_{2} \mathrm{O}(3)$ at $p=0.1 \mathrm{MPa}^{a}$.

\begin{tabular}{|c|c|c|c|c|c|c|c|}
\hline$T(\mathrm{~K})$ & $h\left(\mathrm{~kJ} \cdot \mathrm{kg}^{-1}\right)$ & $T(\mathrm{~K})$ & $h\left(\mathrm{~kJ} \cdot \mathrm{kg}^{-1}\right)$ & $T(\mathrm{~K})$ & $h\left(\mathrm{~kJ} \cdot \mathrm{kg}^{-1}\right)$ & $T(\mathrm{~K})$ & $h\left(\mathrm{~kJ} \cdot \mathrm{kg}^{-1}\right)$ \\
\hline \multicolumn{2}{|c|}{$w_{1+2}=0.55$} & \multicolumn{2}{|c|}{$w_{1+2}=0.60$} & \multicolumn{2}{|c|}{$w_{1+2}=0.65$} & \multicolumn{2}{|c|}{$w_{1+2}=0.70$} \\
\hline 303.15 & 331.04 & 303.15 & 312.51 & 303.15 & 291.33 & 303.15 & 307.99 \\
\hline 313.15 & 354.18 & 313.15 & 334.45 & 313.15 & 312.04 & 313.15 & 327.44 \\
\hline 323.15 & 377.38 & 323.15 & 356.45 & 323.15 & 332.82 & 323.15 & 346.97 \\
\hline 333.15 & 400.70 & 333.15 & 378.56 & 333.15 & 353.70 & 333.15 & 366.60 \\
\hline 343.15 & 424.17 & 343.15 & 400.81 & 343.15 & 374.72 & 343.15 & 386.39 \\
\hline 353.15 & 447.84 & 353.15 & 423.24 & 353.15 & 395.92 & 353.15 & 406.35 \\
\hline 363.15 & 471.75 & 363.15 & 445.91 & 363.15 & 417.34 & 363.15 & 426.54 \\
\hline 373.15 & 495.96 & 373.15 & 468.84 & 373.15 & 439.01 & 373.15 & 446.98 \\
\hline
\end{tabular}

${ }^{a}$ The mass ratio of LiBr to [BMIM]Cl was 2.5:1. Standard uncertainties $u$ were $u(T)= \pm 0.01 \mathrm{~K}, u\left(w_{1+2}\right)= \pm 0.2 \mathrm{wt} . \%$, and $u(p)= \pm 3.0 \mathrm{kPa}$, and the relative standard uncertainty $u_{r}$ was $u_{r}(h)= \pm 0.02 h$.

The fitting equation was as follows:

$$
h=\sum_{i=0}^{2}\left[\left(A_{i}+B_{i} w+C_{i} w^{2}+D_{i} w^{3}\right) T^{i}\right]
$$

Table A12. Values of $A_{i}, B_{i}, C_{i}$, and $D_{i}$ for specific enthalpy.

\begin{tabular}{ccccc}
\hline $\boldsymbol{i}$ & $\boldsymbol{A}_{\boldsymbol{i}}$ & $\boldsymbol{B}_{\boldsymbol{i}}$ & $\boldsymbol{C}_{\boldsymbol{i}}$ & $\boldsymbol{D}_{\boldsymbol{i}}$ \\
\hline 0 & $-1.184934 \times 10^{4}$ & $5.791208 \times 10^{4}$ & $-9.675233 \times 10^{4}$ & $5.399248 \times 10^{4}$ \\
1 & $7.876601 \times 10^{-1}$ & 4.862318 & -5.643877 & $2.016601 \times 10^{-3}$ \\
2 & $4.233235 \times 10^{-3}$ & $-1.054922 \times 10^{-2}$ & $8.114677 \times 10^{-3}$ & $-2.862036 \times 10^{-6}$ \\
\hline
\end{tabular}

\section{References}

1. Ziegler, F.; Kahn, R.; Summerer, F.; Alefeld, G. Multi-effect absorption chillers. Int. J. Refrig. 1993, 16, 301-311. [CrossRef]

2. Misra, R.D.; Sahoo, P.K.; Gupta, A. Thermoeconomic evaluation and optimization of a double-effect $\mathrm{H}_{2} \mathrm{O} / \mathrm{LiBr}$ vapour-absorption refrigeration system. Int. J. Refrig. 2005, 28, 331-343. [CrossRef]

3. Gomri, R.; Hakimi, R. Second law analysis of double-effect vapour absorption cooler system. Energy Convers. Manag. 2008, 49, 3343-3348. [CrossRef]

4. Gomri, R. Second law comparison of single effect and double-effect vapour absorption refrigeration systems. Energy Convers. Manag. 2009, 50, 1279-1287. [CrossRef]

5. Kaushik, S.C.; Arora, A. Energy and exergy analysis of single effect and series flow double-effect water-lithium bromide absorption refrigeration systems. Int. J. Refrig. 2009, 32, 1247-1258. [CrossRef] 
6. Farshi, L.G.; Mahmoudi, S.M.S.; Rosen, M.A. Exergoeconomic comparison of double-effect and combined ejector-double-effect absorption refrigeration systems. Appl. Energy 2013, 103, 700-711. [CrossRef]

7. Avanessian, T.; Ameri, M. Energy, exergy, and economic analysis of single and double effect $\mathrm{LiBr}-\mathrm{H}_{2} \mathrm{O}$ absorption chillers. Energy Build. 2014, 73, 26-36. [CrossRef]

8. Kaynakli, O.; Saka, K.; Kaynakli, F. Energy and exergy analysis of a double effect absorption refrigeration system based on different heat sources. Energy Convers. Manag. 2015, 106, 21-30. [CrossRef]

9. Tanno, K.; Itoh, M.; Sekiya, H.; Yashiro, H.; Kumagai, N. The corrosion inhibition of carbon steel in lithium bromide solution by hydroxide and molybdate at moderate temperatures. Corros. Sci. 1993, 34, 1453-1461. [CrossRef]

10. Muñoz, A.I.; García-Antón, J.; Guiñón, J.L.; Herranz, V.P. Comparison of inorganic inhibitors of copper, nickel and copper-nickels in aqueous lithium bromide solution. Electrochim. Acta 2004, 50, 957-966. [CrossRef]

11. García-García, D.M.; García-Antón, J.; Igual-Muñoz, A.; Blasco-Tamarit, E. Effect of cavitation on the corrosion behaviour of welded and non-welded duplex stainless steel in aqueous LiBr solutions. Corros. Sci. 2006, 48, 2380-2405. [CrossRef]

12. $\mathrm{Hu}, \mathrm{X}$.; Liang, C. Effect of $\mathrm{PWVA} / \mathrm{Sb}_{2} \mathrm{O}_{3}$ complex inhibitor on the corrosion behavior of carbon steel in $55 \%$ LiBr solution. Mater. Chem. Phys. 2008, 110, 285-290. [CrossRef]

13. Kaneko, M.; Isaacs, H.S. Effects of molybdenum on the pitting of ferritic- and austenitic-stainless steels in bromide and chloride solutions. Corros. Sci. 2002, 44, 1825-1834. [CrossRef]

14. Muñoz, A.I.; Antón, J.G.; Guiñón, J.L.; Herranz, V.P. Effect of aqueous lithium bromide solutions on the corrosion resistance and galvanic behaveour of copper-nickel alloys. Corrosion 2003, 59, 32-41. [CrossRef]

15. Guiñón-Pina, V.; Igual-Muñoz, A.; García Antón, J. Influence of PH on the electrochemical behaviour of a duplex stainless steel in highly concentrated LiBr solutions. Corros. Sci. 2011, 53, 575-581. [CrossRef]

16. Blasco-Tamarit, E.; García-García, D.M.; García-Antón, J. Imposed potential measurements to evaluate the pitting corrosion resistance and the galvanic behaviour of a highly alloyed austenitic stainless steel and its weldment in a $\mathrm{LiBr}$ solution at temperatures up to $150{ }^{\circ} \mathrm{C}$. Corros. Sci. 2011, 53, 784-795. [CrossRef]

17. Sánchez-Tovar, R.; Montañés, M.T.; García-Antón, J. Thermogalvanic corrosion and galvanic effects of copper and AISI 316L stainless steel pairs in heavy LiBr brines under hydrodynamic conditions. Corros. Sci. 2012, 60, 118-128. [CrossRef]

18. Sun, J.; Fu, L.; Zhang, S. A review of working fluids of absorption cycles. Renew. Sustain. Energy Rev. 2012, 16, 1899-1906. [CrossRef]

19. Álvarez, M.E.; Esteve, X.; Bourouis, M. Performance analysis of a triple-effect absorption cooling cycle using aqueous (lithium, potassium, sodium) nitrate solution as a working fluid. Appl. Therm. Eng. 2015, 79, 27-36. [CrossRef]

20. Medrano, M.; Bourouis, M.; Coronas, A. Double-lift absorption refrigeration cycles driven by low-temperature heat sources using organic fluid mixtures as working fluids. Appl. Energy 2001, 68, 173-185. [CrossRef]

21. Yin, J.; Shi, L.; Zhu, M.S.; Han, L.Z. Performance analysis of an absorption heat transformer with different working fluid combinations. Appl. Energy 2000, 67, 281-292. [CrossRef]

22. Luo, C.H.; Zhang, Y.; Su, Q.Q. Saturated vapor pressure, crystallization temperature and corrosivity of $\mathrm{LiBr}-[\mathrm{BMIM}] \mathrm{Cl} / \mathrm{H}_{2} \mathrm{O}$ working pair. CIESC J. 2016, 67, 1110-1116.

23. Luo, C.H.; Su, Q.Q.; Mi, W.L. Solubilities, vapor pressures, densities, viscosities, and specific heat capacities of the $\mathrm{LiNO}_{3} / \mathrm{H}_{2} \mathrm{O}$ binary system. J. Chem. Eng. Data 2013, 58, 625-633. [CrossRef]

24. Luo, C.H.; Li, Y.Q.; Chen, K.; Li, N.; Su, Q.Q. Thermodynamic properties and corrosivity of a new absorption heat pump working pair: Lithium nitrate + 1-butyl-3-methylimidazolium bromide + water. Fluid Phase Equilibr. 2017, 451, 25-39. [CrossRef]

25. Li, Y.Q.; Li, N.; Luo, C.H.; Su, Q.Q. Study on a Quaternary Working Pair of CaCl2-LiNO3-KNO3/H2O for an Absorption Refrigeration Cycle. Entropy 2019, 21, 546. [CrossRef]

26. Lee, R.J.; DiGuilio, R.M.; Jeter, S.M.; Teja, A.S. Properties of lithium bromide-water solutions at high temperatures and concentrations II: Density and viscosity. ASHRAE Trans. 1990, 96, 709-714.

27. Iyoki, S.T.; Uemura, T. Heat capacity of water-lithium bromide system and the water-lithium bromide-zinc bromide-lithium chloride system at high temperatures. Int. J. Refrig. 1989, 12, 323-326. [CrossRef] 
28. Wagman, D.D.; Evans, W.H.; Parker, V.B.; Schumm, R.H.; Halow, I.; Bailey, S.M.; Churney, K.L.; Nuttall, R.L. NBS Tables of Chemical Thermodynamic Properties: Selected Values for Inorganic and $C_{1}$ and $C_{2}$ Organic Substances in SI Units; The American Chemical Society and the American Institute of Physics for the National Bureau of Standards: Washington DC, USA, 1982.

29. Kaita, Y. Thermodynamic properties of lithium bromide-water solutions at high temperatures. Int. J. Refrig. 2001, 24, 374-390. [CrossRef]

30. Liu, G.Q.; Ma, L.X.; Liu, J. Handbook of Chemical and Engineering Property Data: Inorganic Volume, 1st ed.; Chemical Industry Press: Beijing, China, 2006.

31. Florides, G.A.; Kalogirou, S.A.; Tassou, S.A.; Wrobe, L.C. Design and construction of a LiBr-water absorption machine. Energy Convers. Manag. 2003, 44, 2483-2508. [CrossRef]

32. Jiang, X.; Cao, Z. A group of simple precise formulations for properties of water and steam. Power Eng. 2003, 23, 2777-2780.

33. Luo, C.H.; Su, Q.Q. Corrosion of carbon steel in concentrated $\mathrm{LiNO}_{3}$ solution at high temperature. Corros. Sci. 2013, 74, 290-296. [CrossRef]

(C) 2019 by the authors. Licensee MDPI, Basel, Switzerland. This article is an open access article distributed under the terms and conditions of the Creative Commons Attribution (CC BY) license (http://creativecommons.org/licenses/by/4.0/). 